\title{
SPECIALIZED COURTS AND THE ADMINISTRATIVE LAWMAKING SYSTEM
}

\author{
RICHARD L. REVESZ $†$
}

The federal judiciary at the Article III level is predominantly generalist, with the district courts and the regional courts of appeals performing the vast majority of the adjudications. ${ }^{1}$ There are, nonetheless, two Article III courts staffed by full-time, specialized judges: the Court of Appeals for the Federal Circuit ${ }^{2}$ and the Court of International Trade. ${ }^{3}$ In addition, there are a number of specialized

$\dagger$ Associate Professor of Law, New York University. I am grateful for the extensive suggestions of Vicki Been, Rochelle Dreyfuss, Samuel Estreicher, Lewis Kornhauser, Eben Moglen, Burt Neuborne, Maurice Rosenberg, Linda Silberman, and Peter Strauss, and for the excellent research assistance of Nicholas Gall. A prior draft of this Article was presented at the Symposium on Federal Courts at the New York University School of Law; I am grateful to Michael Broyde for his valuable assistance on that draft. The Filomen D'Agostino and Max E. Greenberg Research Fund at the New York University School of Law, and the Carnegie Commission on Science, Technology and Government provided financial support.

1 I refer to eleven of the twelve regional courts of appeals with jurisdiction defined primarily by reference to geography - the First through Eleventh Circuitsas generalist, regional circuits. Because of the exclusive jurisdiction of the D.C. Circuit over important federal statutes, I do not include it in this category. See infra text accompanying notes 52-54.

2 The Federal Circuit was created by combining the jurisdictions and judges of the Court of Customs and Patent Appeals and the Court of Claims. See Federal Courts Improvement Act of 1982, Pub. L. No. 97-164, $\S 127(a), 165,96$ Stat. 25, 37-38, 50 (codified as amended at 28 U.S.C. $\$ 1295$ (1982 \& Supp. V 1987)); S. ReP. No. 275, 97th Cong., 2d Sess. 18-22, reprinted in 1982 U.S. Code Cong. \& Admin. NEws 28-32. It is also vested with additional areas of jurisdiction. See infra text accompanying notes 63-66. The features of this court are discussed in Part II.

3 The Court of International Trade had two predecessors. In 1890, Congress established a Board of General Appraisers to review decisions of the Bureau of Customs concerning the classification of goods and the setting of tariffs. See Customs Administration Act of 1890 , ch. 407, 26 Stat. 131. The Board was the first forum for specialized review of administrative action. In 1926, Congress changed the name of the Board of General Appraisers to that of United States Customs Court. See Act of May 28, 1926, ch. 411, 44 Stat. 669. In the 1970s, Congress expanded the jurisdiction of the Customs Court beyond traditional classification and valuation cases to include issues arising out of countervailing duties and non-tariff trade barriers such as the dumping and subsidization of industries. See Cohen, The New United States Court of International Trade, 20 Colum. J. TRANSNat'l L. 277, 281 (1981). Consistent with these changes, the Customs Courts Act of 1980 renamed the court as the United States Court of International Trade. See Customs Courts Act of 1980, Pub. L. No. 96-417, § 101, 94 Stat. 1727, 1727 (codified as amended at 28 U.S.C. $\S 251$ (1982)). The features of this court are discussed in Part II. 
courts, staffed part-time by generalist judges, such as the Temporary Emergency Court of Appeals, ${ }^{4}$ the Special Court formed under the Regional Rail Reorganization Act of $1973,{ }^{5}$ the Foreign Intelligence Surveillance Court and the Foreign Intelligence Surveillance Court of Review, ${ }^{6}$ and the division of the D.C. Circuit that appoints independent counsel under the Ethics in Government Act. ${ }^{7}$

The existing Article III specialized courts are charged primarily with the review of administrative action, ${ }^{8}$ as are some Article I courts, such as the Tax Court $^{9}$ and the newly created Court of Veter-

4 The Temporary Emergency Court of Appeals was created by the Economic Stabilization Act Amendments of 1971, Pub. L. No. 92-210, § 211(b), 85 Stat. 743, 749. The features of this court are discussed in Part II.

5 Regional Rail Reorganization Act of 1973, Pub. L. No. 93-236, § 209(b), 87 Stat. 985,999 (codified as amended at 45 U.S.C. $\S 719$ (b) (1982)). The judges, who serve part-time on the Special Court, are selected by the Judicial Panel on Multidistrict Litigation. See id. The court, which operates as a three-judge district court, see id., is empowered to review "matters concerning the value of the rail properties to be conveyed under the [reorganization] plan and the value of the consideration to be received for such properties." Id. $\$ 719$ (a).

6 These courts were established by the Foreign Intelligence Surveillance Act of 1978, Pub. L. No. 95-511, § 103, 92 Stat. 1783,1788 (codified at 50 U.S.C. $\S 1803$ (1982)). The Foreign Intelligence Surveillance Court, which consists of seven U.S. district judges designated by the Chief Justice of the United States, rules on applications for electronic surveillance orders. See 50 U.S.C. \& 1803(a) (1982). The Foreign Intelligence Surveillance Court of Review, which consists of three U.S. district or circuit court judges designated by the Chief Justice, reviews denials by the Foreign Intelligence Surveillance Court of applications for electronic surveillance orders. See id. $\$ 1803$ (b). The decisions of both courts are issued under seal, see id. $\S 1803(a)-(b)$, and even the statistics revealing the number of applications for court orders are classified, see K. Redden, Federal Special Court Litigation $\$ 7.1$ (1982).

7 Ethics in Government Act of 1978, Pub. L. No. 95-521, §602(a), 92 Stat. $1824,1873-74$ (codified as amended at 28 U.S.C. $\$ 49$ (1982 \& Supp. V 1987)). The court consists of three circuit court judges or justices appointed by the Chief Justice of the United States, at least one of whom must be a judge of the D.C. Circuit. See id. $\S 49$ (d). Priority must be given to senior judges or retired justices. See id. $\S 49$ (c). The judges are appointed for two-year terms. See id. § 49(a). The constitutionality of this mechanism for appointing prosecutors was upheld in Morrison v. Olson, 487 U.S. 654 (1988).

8 Even in the nineteenth century, however, there were specialized courts not charged with the review of administrative action. The earliest specialized court was the United States Court of Claims, which was established to hear private claims against the United States. See Act of Feb. 24, 1855, ch. 122, 10 Stat. 612. Also in the nineteenth century, Congress established a temporary Court of Private Land Claims to adjudicate land claims in the territory acquired from Mexico under the treaties of Guadaloupe-Hidalgo and Mesilla. See Act of Mar. 3, 1891, ch. 539, 26 Stat. 854-55.

9 The Tax Court had two predecessors. The Board of Tax Appeals was created in 1924 to provide an independent tribunal to hear appeals from taxpayers after they had been notified of a tax deficiency but before they had paid the tax. See Revenue Act of 1924, ch. 234, $\$ 900,43$ Stat. 253, 336-38. In 1942, the Board was renamed the Tax Court of the United States. See Revenue Act of 1942, ch. 619, $\$ 504,56$ Stat. 
ans Appeals. ${ }^{10}$ Similarly, most of the proposals for specialization have focused on the review of decisions of groups of agencies ${ }^{11}$ or individual agencies. ${ }^{12}$ The specialized review of administrative

798, 957. Interestingly, although the original legislation had proposed that the Board be named the "United States Tax Court," the name was changed apparently at the request of Commerce Clearing House, which published a series entitled "United States Tax Cases." The publisher was concerned that the initials of court would be confused with the initials of the series. See H. Dubroff, The United States Tax Court: An Historical Account 184 (1979). The Tax Reform Act of 1969 changed this court's name to United States Tax Court. See Tax Reform Act of 1969, Pub. L. No. 91-172, § 951, 83 Stat. 487, 730 (codified as amended at 26 U.S.C. $§ 7441$ (1982 \& Supp. V 1987)). The features of the Tax Court are discussed in Part II.

10 In November 1988, Congress established the United States Court of Veterans Appeals as an Article I court. See Veterans' Judicial Review Act, Pub. L. No. 100-687, $\S 301,102$ Stat. 4105,4113 (1988) (to be codified at 38 U.S.C. $\$ \S 4051-92$ ). The legislation creating this court was addressed principally to two controversial features of the statutory scheme governing veterans' benefits: the then-existing preclusion of judicial review, see 38 U.S.C. $\$ 211$ (1982) (amended by Veterans' Judicial Review Act, supra, § 101, 102 Stat. at 4105); cf. Johnson v. Robison, 415 U.S. 361 (1974) (holding that preclusion of review did not extend to actions challenging the constitutionality of veterans' benefits legislation); and the $\$ 10$ limitation on the fee payable to attorneys who represented claimants before the Veterans' Administration. See 38 U.S.C. \$ 3404(c) (1982) (amended by Veterans' Judicial Review Act, supra, $\S 104,102$ Stat. at 4108-09)); H.R. REP. No. 963, 100th Cong., 2d Sess. 9-22, reprinted in 1988 U.S. CoDE Cong. \& ADMIN. News 5782, 5790-5804; see also Walters v. National Ass'n of Radiation Survivors, 473 U.S. 305, 319-34 (1985) (upholding the limitation). The features of the Court of Veterans Appeals are discussed in Part II.

Other Article I courts include the territorial courts and the military courts. See, e.g., Northern Pipeline Constr. Co. v. Marathon Pipe Line Co., 458 U.S. 50, 63-76 (1982). For discussions of the status of Article I courts, also known as legislative (as opposed to constitutional) courts, see M. ReDish, Federal JuRISDiction: Tensions in the Allocation of Judicial Power 35-51 (1980); Fallon, Of Legislative Courts, Administrative Agencies, and Article III, 101 HARv. L. REv. 915, 949-92 (1988).

11 In 1936, the Special Committee on Administrative Law of the American Bar Association recommended the creation of a United States Administrative Court, combining the jurisdictions of the Court of Claims, the Court of Customs and Patent Appeals, the Customs Court, and the Board of Tax Appeals, and adding various other areas. See, e.g., Report of the Special Comm. on Administrative Law, 61 ANN. ReP. A.B.A. 720, 760-63 (1936); Caldwell, $A$ Federal Administrative Court, 84 U. PA. L. Rev. 966, 979-81 (1936) (outlining the major classes of cases that would be adjudicated by the Administrative Court). In the mid-1950s, the Hoover Commission proposed an Administrative Court of the United States that would include a tax section, a trade section and a labor section. See infra notes 34-37. In 1971, the President's Advisory Council on Executive Organization, known as the Ash Council, recommended the establishment of an Administrative Court with jurisdiction over transportation, securities, and power cases. See President's Advisory Council on Executive Organization, A New Regulatory Framework: Report on Selected Independent Regulatory Agencies 54 (1971); see also Nathanson, The Administrative Court Proposal, 57 VA. L. REv. 996, 997-1003 (1971) (examining the underlying assumptions of the Ash Council proposal and drawing lessons from the historical experience of other specialized courts).

12 The proposal for a Court of Tax Appeals is discussed infra text accompanying 
action raises issues distinct from those presented by specialized adjudication in non-administrative contexts-issues that the academic literature has not adequately explored. ${ }^{13}$

First, where Congress has delegated authority to administrative agencies, Article III review of administrative action is only one component of a complex set of relationships among Congress, administrative agencies, Article I courts, and Article III courts, as well as among the different levels and jurisdictions of the Article III judiciary. The sum of these relationships defines what might be called the administrative lawmaking system. As I discuss below, the replacement of generalist review with specialized review is likely to affect other components of the system-notably the process of delegation of congressional authority to administrative agencies.

Second, one of the traditional reasons for creating administrative agencies is to produce a uniform interpretation of federal statutes. ${ }^{14}$ Thus, absent countervailing goals, agency action should be subject to review in a single forum, rather than in the regional circuits where disuniformity can arise because of the absence of intercircuit stare decisis. ${ }^{15}$

Third, administrative agencies are specialized institutions. The nature of the judicial review of agency decisions therefore gives rise

notes $20-22$. In the early 1960s, there was a proposal for a United States Economy Court, which would have jurisdiction over disputes between labor unions and corporate managements over unfair labor practices and arising out of the interpretation or modification of labor-management agreements. See Kutner, Due Process of Economy: A Proposal for a United States Economy Court, 15 U. Miami L. Rev. 341, $357-60$ (1961). In the 1970s, there were proposals for a Selective Service Court, see Donahue, The Supreme Court vs. Section 1O(b)(3) of the Selective Service Act: A Study in Ducking Constitutional Issues, 17 LICLA L. REv. 908, 955-68 (1970), and for an Environmental Court, see Whitney, The Case for Creating a Special Environmental Court System, 14 WM. \& MARY L. Rev. 473, 475-504 (1973). In the 1980s, there were proposals for an Immigration Court, see Roberts, Proposed: A Specialized Statutory Immigration Court, 18 SAN Diego J. Rev. 1, 1-20 (1980), and for a Social Security Court, see H.R. 3865, 97th Cong., 1st Sess. (1981); Arner, The Social Security Court Proposal: An Answer to a Critique, 10 J. on Legis. 324 (1983).

13 For thoughtful contemparary discussions of specialized courts, see $\mathrm{H}$. Friendly, Federal Jurisdiction: A General View 153-96 (1973); R. Posner, The Federal Courts: Crisis and Reform 147-60 (1985); Jordan, Specialized Courts: $A$ Choice, 76 Nw. U.L. Rev. 745, 745 (1981); Posner, Will the Federal Courts of Appeals Survive Until 1984?: An Essay on Delegation and Specialization of the Judicial Function, $56 \mathrm{~S}$. CAL. L. REv. 761, 775-91 (1983). For an illuminating analysis of one specialized court, see Dreyfuss, The Federal Circuit: $A$ Case Study in Specialized Courts, 64 N.Y.U. L. REv. 1 (1989).

14 See J. Landis, The Admintstrative Process 33 (1938).

15 See S. Estreicher \& J. Sexton, Redefining the Supreme Court's Role 48 (1986); Estreicher \& Revesz, Nonacquiescence by Federal Administrative Agencies, 98 YALE L.J. 679,736 \& n.275 (1989); infri text accompanying notes 175-78. 
to distinct questions about the optimal mix of generalist and specialized decisionmaking. In particular, it is important to consider whether the arguments that lead to the creation of a specialized agency apply with equal force to specialized judicial review.

Fourth, one rationale for specialization is exclusive to the administrative context. Since the New Deal, there have been many proposals to remove adjudicative functions from administrative agencies, vesting these functions instead in specialized courts. Such proposals have been motivated by criticisms of the impartiality of adjudications by agencies that combine rulemaking, adjudicatory, and enforcement functions. ${ }^{16}$

The central purpose of this Article is to analyze the desirability of vesting the review of administrative action in specialized courts, and to assess the relative merits of different types of specialized courts. Part I presents the central arguments raised in favor of specialized courts. Part II discusses the varieties of specialized courts (courts currently in place, courts that once existed and were subsequently abolished, and various proposals), and sets forth a method by which to categorize such courts. In general, the academic literature has not paid proper attention to the different structures of specialized courts. ${ }^{17}$ As a result of these differences, arguments for and against specialized courts need to be tailored more carefully to the type of specialized court being analyzed.

Part III analyzes a model of congressional delegation to administrative agencies. ${ }^{18^{\prime}}$ It seeks to ascertain how the replacement of generalist review with specialized review affects the interaction between Congress and agencies. Part IV discusses the impact of specialized courts on the judicial system. It studies their effect both on dialogue among the various actors in the system and on the coherence of federal law. Part $\mathrm{V}$ explains why, in the context of judicial review of administrative action, there should be a presumption against establishing specialized courts to replace the functions of the regional, generalist courts of appeals. The arguments that counsel against specialization in this context, however, do not apply to specialized courts that are subject to review by the generalist courts of appeals. This Part discusses how many of the asserted benefits of specialization can be attained by such courts.

16 This rationale is discussed infra text accompanying notes 34-41.

17 One notable exception is discussed infra note 48 .

18 Various mathematical propositions concerning this model are proved in the Appendix. 


\section{The Arguments in Favor of Specialized Review of ADMINISTRATIVE ACTION}

Throughout this century, and particularly since the New Deal, there have been frequent calls-some successful, many unsuccessful-for the establishment of specialized courts in a wide range of areas, at either the Article III or the Article I level.

Supporters of judicial specialization maintain, first, that specialized courts will enhance the uniformity of decisions by eliminating review in multiple circuits under a legal regime in which there is no intercircuit stare decisis. ${ }^{19} \mathrm{~A}$ broad argument for uniformity would counsel for the adoption of intercircuit stare decisis. But implicit in the lack of intercircuit stare decisis is a view about the benefits of percolation-discussed in Part IV-that many proponents of specialization would not disturb. The narrower view is that specialized courts are desirable where there is a particularly compelling argument for uniformity.

An asserted special need for uniformity in tax law was an important underpinning of the unsuccessful proposals for the creation of a Court of Tax Appeals with exclusive appellate jurisdiction over all civil decisions in federal tax cases. ${ }^{20}$ Because of the somewhat idiosyncratic system for judicial review of tax cases, which is explained in more detail below, ${ }^{21}$ disuniformity could produce serious forum shopping problems. ${ }^{22}$

The possibility of forum shopping as a result of disagreements among the circuits also played a role in the creation of the Federal Circuit as a court of exclusive appellate jurisdiction over patents. ${ }^{23}$ Professor Dreyfuss notes:

[I] the period 1945-195 $\%$, a patent was twice as likely to be held valid and infringed in the Fifth Circuit than in the Seventh Circuit,

19 See Currie \& Goodman, Judicial Review of Federal Administrative Action: Quest for the Optimum Forum, 75 Colum. L. Rev. 1, 65 (1975); Meador, An Appellate Court Dilemma and a Solution through Subject Matter Organization, 16 U. Mich. J.L. REF. 471, 475-82 (1983).

20 See Griswold, The Need for a Court of Tax Appeals, 57 Harv. L. Rev. 1153 (1944). Although Griswold's proposal was not the first, see, e.g., Traynor, Administrative and Judicial Procedure for Federal Income, Estate, and Gift Taxes-A Criticism and a Proposal, 38 Colum. L. Rev. 1393, 1427-29 (1938); Lowndes, Taxation and the Supreme Court, 1937 Term, (pt. 2), 87 U. PA. L. Rev. 165, 200 (1938), it was the most influential, see Miller, A Court of Tax Appeals Revisited, 85 Yale L.J. 228, 229 (1975).

21 See infra text accompanying notes 57-60.

22 See H. FriendLY, supra note 13, at 161.

23 See S. REP. No. 275, supra note 2, at 2-4, reprinted in 1982 U.S. CODE CONG. \& Admin. News at 12-14. 
and almost four times more likely to be enforced in the Seventh Circuit than in the Second Circuit. It is no wonder that forum shopping was rampant. ... [W]ithout knowing where a patent would be litigated, it became impossible to adequately counsel technology developers or users. In such a legal environment, the promise of a patent could hardly be considered sufficient incentive to invest in research and development. ${ }^{24}$

Similarly, the creation of the Court of Customs Appeals in $1909^{25}$ was premised in large part on the special evils of disuniformity in the application of customs duties. One commentator argued that the enhanced need for uniformity flows from the constitutional dictate that "all Duties, Imposts, and Excises shall be uniform throughout the United States,"26 and that this dictate applies not only to the imposition of duties, but also to their application. ${ }^{27}$

A second argument for specialized courts is based on the proposition that such courts promote the coherence of a statutory scheme. The Federal Circuit, for example, is credited with bringing coherence to the field of patent law. ${ }^{28}$ Coherence is a concept distinct from consistency. Inconsistency results when the legal system contains two contradictory rules, which occurs, for example, when two circuits disagree with one another. ${ }^{29}$ Coherence, in contrast, demands not only that the legal rules of a statutory scheme be consistent but also that they reflect a unitary vision of that scheme. ${ }^{30}$

Third, proponents of specialization argue that specialized courts are more likely to make correct decisions in complex areas. A particular subject matter may be complex due to the difficulty of the underlying law. The classic example of a legally complex field is tax law. ${ }^{31}$

Alternatively, the complexity may derive from the technical nature of the facts. For example, arguing in favor of a specialized patent court, Judge Friendly noted that

courts must ... deal today with a great number of patents in the higher reaches of electronics, chemistry, biochemistry, pharmacol-

24 Dreyfuss, supra note 13 , at 7.

25 Tariff Act of 1909, ch. 6, $\S 29,36$ Stat. 11, 106.

26 U.S. ConsT. art I, § 8. (1974).

27 See Rao, A Primer on Customs Court Practice, 40 Brooklyn L. Rev. 581, 585

28 See Dreyfuss, supra note 13, at 66.

29 See Kornhauser \& Sager, Unpacking the Court, 96 YaLE L.J. 82, 104-05 (1986).

30 See id. at 105.

31 See Jordan, supra note 13, at 750 ("What makes tax law unique is the intricacy and complexity of the scheme embodied in the Internal Revenue Code."). 
ogy, optics, harmonics and nuclear physics, which are quite beyond the ability of the usual juclge to understand without the expenditure of an inordinate amount of educational effort by counsel and of attempted self-education by the judge, and in many instances, even with it. ${ }^{32}$

Concern over the complexity of factual determinations prompted Congress, at the time that it passed the Clean Water Act, to request that the President study the desirability of establishing a specialized court with jurisdiction over environmental matters. ${ }^{33}$

Fourth, as I already discussed, specialized courts have been promoted as a means to remove adjudications from administrative agencies. A wide ranging proposal motivated in part by this concern was advanced in the 1950 s by the Commission on Organization of the Executive Branch of the Government, popularly known as the Hoover Commission after its chairman Herbert Hoover. The Commission recommended the establishment of an Administrative Court of the United States, which would consist of three sections: a tax section that would replace the tax court; a trade section, to which the adjudicatory jurisdiction of a number of agencies dealing with trade regulation would be transferred; and a labor section, to which the adjudicatory jurisdiction of the National Labor Relations Board would be transferred. ${ }^{34}$ In support of the proposal, the Commission noted:

Where the proceeding before the administrative agency is strictly judicial in nature, and the remedy afforded by the agency is one characteristically granted by the courts, there can be no effective

$32 \mathrm{H}$. FRIENDLY, supra note 13, at 156-57. A related argument for specialization derives from economic theory and maintains that through division of labor, society can reduce the cost of performing services. See Posner, supra note 13, at 776. As Adam Smith noted, "the very different genius which appears to distinguish men of different professions ... is not upen many occasions so much the cause, as the effect of the division of labour." A. SMrth, AN Inquiry Into the Nature and Causes of the Wealth of Nations 27 (L. von Mises ed. 1953) (1776). Of course, the broad application of this argument would counsel against any use of generalist judges. A narrower argument, however, is that certain areas are so complex that it is inefficient for a generalist judge to learn about them.

33 See Federal Water Pollution Control Act Amendments of 1972, Pub. L. No. 92-500, § 9, 86 Stat. 816, 899; H.R. ReP. No. 911, 92d Cong., 2d Sess. 143 (1972). Ultimately, such a court was not established. See Report of the President, Acting Through the Attorney General, on the Feasibility of Establishing an Environmental Court System (1973) [hereinafter cited as Report of THE President]. For commentary, see Whitney, supra note 12.

34 See Comm'n on Organization of the Executive Branch of Government, Legal Services and Procedures: A Report to Congress 87-88 (1955) (Recommendation No. 51). 
protection of private rights unless there is a complete separation of the prosecuting functions from the functions of decision. ${ }^{35}$

A central idea behind the proposal was that mature agencies would not need adjudicatory functions to carry out their mandates; they would be able to set policy through rulemaking. Thus, when other agencies achieved such maturity, additional adjudicatory functions would be transferred to the Administrative Court, as there would be no functional justification for continuing to permit agencies to combine functions. ${ }^{36}$ Describing this proposal, one commentator observed: "An administrative court is not an end in itself, but is rather a means to the end of complete separation of judicial functions from the administrative process." 37

Similar concerns motivated the establishment of the Board of Tax Appeals, ${ }^{38}$ a predecessor of the Tax Court, to hear appeals from taxpayers after they had been notified of a tax deficiency but before they had paid the tax. Prior to the Board's creation, the Committee on Appeals and Review within the Bureau of Internal Revenue-the predecessor to the Internal Revenue Service (IRS)-heard these appeals. ${ }^{39}$ A special board created by the Revenue Act of $1921^{40}$ to study this appellate scheme concluded:

[I]t would never be possible to give to the taxpayer the fair and independent review to which he is of right entitled as long as the appellate tribunal is directly under, and its recommendations subject to the approval of, the officer whose duty it is to administer the law and collect the tax. As long as the appellate tribunal is part and parcel of the collecting machinery it can hardly maintain the attitude essential to a judicial tribunal. ${ }^{41}$

35 Id. at $84-85$.

36 See id. at 84,88 .

37 Minor, The Administrative Court: Variations on a Theme, 19 Oнго Sт. L.J. 380, 384 (1958). For other commentary, see Jaffe, Basic Issues: An Analysis, 30 N.Y.U. L. Rev. 1273 (1955); Freer, The Case Against the Trade Regulation Section of the Proposed Administrative Court, 24 Geo. WaSh. L. Rev. 637 (1956).

38 See supra note 9.

39 See H. Dubroff, supra note 9, at 39-41.

40 Revenue Act of 1921, ch. 136, $\S 1327,42$ Stat. 227, 317.

41 Report of Tax Simplification Board, H.R. Doc. No. 103, 68th Cong., lst Sess. 4 (1923) (quoted in H. Dubroff, supra note 9, at 44).

Unease with the combination of functions in a single agency led to the creation of the Occupational Safety and Health Review Commission and the Federal Mine Safety and Health Review Commission. See Johnson, The Split-Enforcement Model: Some Conclusions from the OSHA and MSHA Experiences, in ADMIN. Conference of THE United States, Recommendations and Reports 293, 296-302 (1986); infra text accompanying notes 115-26. 
Fifth, the sharp increase in the volume of litigation in the past decade provides another argument for specialization. It is reasonably clear that there are limits to how much generalist courts can continue to grow without some, perhaps substantial, deterioration in the quality of their output. ${ }^{4 \cdot 2}$ For example, increasing the number of judges in each court of appeals will reduce the uniformity of law within each circuit; increasing the number of courts of appeals will deprive those courts of their regional perspective and place further pressure on the Supreme Court's docket; increasing each judge's caseload will compromise the quality of adjudication; and some of these options will also diminish the prestige attached to a judgeship. ${ }^{43}$

Proponents of specialized courts argue that the legal system can preserve high-quality generalist courts only by transferring jurisdiction over certain administrative areas to specialized courts. For example, Justice Scalia has noted that, in the absence of a workload problem, specialized courts might not be desirable: "I understand the aversion that all we cornmon-law lawyers have for the 'specialist' judge; even in a matter as specialized as tax, the disadvantage of inexperience is often more than made up for by the advantage of a fresh outlook and broad viewpoint."44 He added that "[i]t would be wonderful to give all federal litigants, and all cases, the benefit of an old-fashioned, generalist federal judge." $45 \mathrm{He}$ concluded, however, that "if, through such specialized courts, a substantial amount of business could be diverted from the regular federal courts, the latter would have a chance of rernaining in the future what they have been in the past." 46

Under this rationale, specialization is appropriate in areas in which there is a high volume of relatively routine cases. The generalist courts would thus be relieved of considerable workload while retaining control over the significant areas of federal law. Justice

42 See, e.g., R. Posner, supra note 13, at 94-129; Carrington, Crowded Dockets and the Courts of Appeals: The Threat to the Function of Review and the National Law, 82 HARv. L. REv. 542 (1969); Meador, The Foderal Judiciary-Inflation, Malfunction, and a Proposed Course of Action, 1981 B.Y.U. L. REv. 617.

43 See R. Posner, supra note 13, at 99-100.

44 Remarks by Justice Antonin Scalia Before the Fellows of the American Bar Foundation and the National Conference of Bar Presidents 9-10 (Feb. 15, 1987) [hereinafter Remarks by Justice Antonin Scalia].

$45 \mathrm{Id}$. at 10.

46 Id. 
Scalia has argued, on this account, that specialized courts are desirable for social security and freedom of information cases. ${ }^{47}$

\section{Varieties of Specialized Review of Agency Action}

There is rich diversity in the types of specialized courts that populate the administrative landscape. ${ }^{48}$ Moreover, the issues raised by specialization depend critically on the characteristics of the specialized court. This Part has two objectives. First, it categorizes specialized courts reviewing administrative action according to the three criteria that are central to the analysis in the remainder of the Article: jurisdiction, staffing, and hierarchical relationship to the generalist courts. Second, it places within this taxonomy the existing and former specialized courts, as well as various proposed courts. Without a detailed categorization, it is simply not possible to provide a rigorous analysis of the desirability of specialized courts.

\section{A. The Jurisdiction of Specialized Courts}

In considering the jurisdiction of specialized courts, two variables are relevant: exclusivity and limitation. Exclusivity distinguishes between courts that hear every case of a certain type (courts of exclusive jurisdiction) and courts that do not hear every case of a certain type (courts of non-exclusive jurisdiction). Limitation distinguishes between courts that hear only a particular type of case (courts of limited jurisdiction) and courts that hear the full range of federal cases (courts of unlimited jurisdiction). While actual courts will lie somewhere on a continuum defined by the degree of exclusivity and the degree of limitation, it is helpful to present the taxonomy in binary terms.

47 See id. at 8.

48 The academic literature has generally ignored this diversity. The most comprehensive effort to date defines four categories: "(1) simple specialized courts; (2) specialized courts with generalized judges; (3) generalized courts with exclusive special jurisdiction; and (4) panels with categorical case assignments." $P$. Carrington, D. Meador \& M. Rosenberg, Justice on Appeal 167-68 (1976). These categories are not sufficiently precise to perform the analysis of Parts III and IV. It matters, for example, whether the specialized court has exclusive jurisdiction and whether it is subject to review by the generalist courts of appeals. 
Table I: Jurisdiction of Specialized Courts

\begin{tabular}{l|c|c|c}
\multicolumn{2}{c}{} & \multicolumn{2}{c}{ Exclusivity } \\
\cline { 3 - 4 } & & Non-Exclusive & Exclusive \\
\hline \multirow{2}{*}{ Limitation } & Unlimited & Class A & Class B \\
\cline { 2 - 4 } & Limited & Class C & Class D \\
\hline
\end{tabular}

1. Unlimited, Non-Exclusive Jurisdiction

Courts in Class A, which enjoy non-exclusive and unlimited jurisdiction, are not specialized courts at all, since the distribution of cases to them is not controlled in any way. This category consists of the federal district courts and the regional courts of appeals, with the prominent exception of the D.C. Circuit, which enjoys exclusive jurisdiction with respect to certain questions that arise under important federal statutes. ${ }^{49}$

The courts of appeals fall into this category because of the absence of intercircuit stare decisis, which permits the circuits to disagree with each other. ${ }^{50}$ If, instead, there were intercircuit stare decisis, the federal appellate system would essentially be akin to a single court with exclusive jurisdiction over its subject matter.

Two clarifications are in order. First, of course, the federal courts are courts of limited subject-matter jurisdiction. Second, to the extent that the D.C. Circuit enjoys exclusive jurisdiction in certain areas, the jurisdiction of the other courts of appeals is correspondingly limited to exclude those areas. I describe a court's jurisdiction as unlimited to the extent that it is not significantly constrained beyond the requirements of federal jurisdiction. For the remainder of this Article, I refer to courts in Class A as generalist courts.

49 See infra text accompanying notes 52-54. 80 .

50 See supra text accompanying notes 14-15; infra text accompanying notes 175- 


\section{Unlimited, Exclusive Jurisdiction}

Courts in Class B hear all cases within the domain of federal jurisdiction and have exclusive jurisdiction over some set of cases. The degree of specialization of such courts will depend on the percentage of cases in their docket that fall within their exclusive jurisdiction. This method of specialization is primarily designed to achieve uniformity in the judicial system; it is used for statutory schemes in which national uniformity is a particularly important goal. ${ }^{51}$

As noted above, the D.C. Circuit enjoys exclusive jurisdiction over the review of decisions of various administrative agencies. For example, it has exclusive jurisdiction over the review of standards promulgated by the Environmental Protection Agency, ${ }^{52}$ as well as over the review of certain orders and actions of the Federal Communications Commission ${ }^{53}$ and the Federal Election Commission. ${ }^{54}$ There also have been proposals for vesting other regional circuits with exclusive jurisdiction over the review of agency determinations. Professors David Currie and Frank Goodman have suggested that "SEC cases, for example, might be parceled out to the Second Circuit; FPC cases to the Fifth; CAB cases to the Third, and so on."55

\section{Limited, Non-Exclusive Jurisdiction}

Courts in Class C, which are characterized by limited, non-exclusive jurisdiction, are divided into two types. The first consists of specialized courts that are organized into circuits. Each circuit then has non-exclusive jurisdiction even though, in the aggregate, the circuits enjoy jurisdiction over the whole subject matter. For example, an early congressional proposal for judicial review of decisions of the Interstate Commerce Commission (ICC), presented at the turn of

51 See, e.g., statutes cited infra note 52.

52 See, e.g., Safe Drinking Water Act, 42 U.S.C. § 300j-7(a) (1982 \& Supp. V 1987); Clean Air Act, 42 U.S.C. $\$ 7607$ (b) (1982); Comprehensive Environmental Response, Compensation, and Liability Act, 42 U.S.C. $\$$ 9613(a) (1982).

53 See 47 U.S.C. $\S 402$ (b) (1982).

54 See 2 U.S.C. $\S 437 g(a)(8)(A)$ (1988).

55 Currie \& Goodman, supra note 19, at 75. Along somewhat different lines, Professor Meador has proposed subject matter organization within each of the courts of appeals, under which stable panels of judges would be assigned specified portions of the court's caseload. Panels would rotate every few years. See Meador, supra note 19 , at 475-84; Meador, supra note 42, at 645-47. 
the century, called for the creation of Circuit Courts of Interstate Commerce, one in each judicial circuit. ${ }^{56}$

The second, and more common, type consists of specialized courts that decide only cases of a particular type but that decide less than all of the cases of that type. The Tax Court is perhaps the most prominent example of this type of jurisdiction. Taxpayers who are assessed a deficiency by the IRS have several courses of action. They can refuse to pay the deficiency and contest the IRS's determination in the Tax Court. ${ }^{57}$ Alternatively, they can pay the deficiency and sue for a refund in either the district court or the Claims Court. ${ }^{58}$ On the appellate level there is also no exclusive jurisdiction. Decisions of both the Tax Court and the district courts are appealable to

56 See Rightmire, Special Federial Courts-II, 13 ILl. L. REv. 97, 98 (1918). When the Commerce Court was ultimately created in 1910, it was organized as a single unit. See Act of June 18, 1910, ch. 309, § 1, 36 Stat. 539, 539-42.

57 See 26 U.S.C. $\S \S 7451-65$ (1982) (jurisdiction of the Tax Court over deficiency determinations). For analyses of the jurisdiction of the Tax Court, see, e.g., Brown, The Nature of the Tax Court of the United States, 10 U. PrTT. L. Rev. 298, $298-$ 300 (1949); Ferguson, Jurisdictional Problems in Federal Tax Controversies, 48 Iowa L. REV. 312 (1963).

58 See 26 U.S.C. $§ 7422$ (1982) (jurisdiction of Claims Court and district courts over refund suits).

Judge Friendly has labeled the Tax Court's lack of exclusive jurisdiction over the deficiency determinations of the JRS, "the result of history rather than logic." $H$. FrIENDLY, supra note 13, at 161. There has been vigorous debate over the wisdom of extending the court's jurisdiction. Compare, e.g., id. at 171 (favoring extension of Tax Court jurisdiction) and Traynor \&: Surrey, New Roads Toward the Settlement of Federal Income, Estate and Gift Tax Controversies, 7 LAw \& ConTEMP. Probs. 336, 347-48 (1940) (same) and Traynor, supra note 20, at 1425-26 (same) with Griswold, supra note 20, at 1 185-86 (opposing extension of Tax Court jurisdiction) and Prettyman, $A$ Comment on the Traynor Plan for Revision of Federal Tax Procedure, 27 GEo. L.J. 1038, 1048-49 (1939) (same) and Sutherland, New Roads to the Settlement of Tax Controversies: $A$ Critical Comment, 7 Law \& Contemp. Profis. 359, 360-61 (1940) (same).

For a study advocating optional, specialized alternatives to the generalist courts beyond the confines of the tax area, see Jordan, supra note 13 . 
the regional circuit in which the taxpayer resides. ${ }^{59}$ In contrast, decisions of the Claims Court are appealable to the Federal Circuit. ${ }^{60}$

Similarly, before the creation of the Federal Circuit, the Court of Customs and Patent Appeals had jurisdiction only over appeals from patent denial and interference decisions of the Patent Office-later, the Patent and Trademark Office (PTO). ${ }^{61}$ This jurisdiction did not extend to infringement cases, which were brought in the district courts and appealed to the regional courts of appeals. ${ }^{62}$

\section{Limited, Exclusive Jurisdiction}

A court in Class D hears only cases of a particular type, and hears all cases of that type. The most prominent example of such a court is the Federal Circuit. In the patent area, this court inherited the appellate jurisdiction of the Court of Customs and Patent Appeals, ${ }^{63}$ as well as the jurisdiction over appeals from district court

59 See 26 U.S.C. $\$ 7482$ (b) (1982) (venue provision for appeals from Tax Court); 28 U.S.C. $\S \S 1294,1402$ (a) (1982) (venue provisions for cases filed in district courts).

Since 1970, the Tax Court has followed the case law of the court of appeals that will review its decision, whenever the identity of this court is easily ascertainable. See Golsen v. Commissioner, 54 T.C. 742, 756-57 (1970), aff'd, 445 F.2d 985 (10th Cir.), cert. denied, 404 U.S. 940 (1971). Thus, tax cases are appealed to the same court of appeals regardless of whether they originate in the Tax Court or the district courts, but not if they originate in the Claims Court. See Estreicher \& Revesz, supra note 15, at $713 \mathrm{n} .175$.

60 See 28 U.S.C. $\$ 1295(a)(3)$ (1982) (appellate review of the Claims Court decisions by the Federal Circuit).

These multiple avenues for appellate review would have been eliminated by the proposed Court of Tax Appeals. See supra text accompanying notes 20-22.

61 See Act of Mar. 2, 1929, ch. 488, 45 Stat. 1475. The patent jurisdiction of this court did not change significantly over the course of its existence. See Gholz, Patent and Trademark Jurisdiction of the Court of Customs and Patent Appeals, 40 GEo. Wash. L. REv. 416, 417-20 (1971).

For a review of earlier legislative proposals to create a specialized court in the patent area, see F. Frankfurter \& J. Landis, The Business of the Supreme Court 174-84 (1928).

62 See 28 U.S.C. $\$ 1338$ (1982) ("The district courts shall have original jurisdiction . . . arising under any Act of Congress relating to patents . . . . Such jurisdiction shall be exclusive ....."); id. $\$ 1291$ (providing for appeal from district courts to courts of appeals); see also Dreyfuss, supra note 13, at 21.

In addition, the jurisdiction of the Court of Customs and Patent Appeals was not exclusive even as to challenges of PTO decisions. A litigant dissatisfied with a determination of the PTO had the option of bringing a civil suit in the District Court for the District of Columbia, with the right of appeal to the D.C. Circuit. See Adams, The Court of Appeals for the Federal Circuit: More than a National Patent Court, 49 Mo. L. REv. 43, 51 (1984).

63 See 28 U.S.C. $\S 1295(\mathrm{a})(4)(\mathrm{A})(1982)$. 
decisions that was previously vested in the regional circuits. ${ }^{64}$ The Federal Circuit also has exclusive jurisdiction to review various other administrative determinations. ${ }^{65}$ Consequently, although the Federal Circuit is the thirteenth federal judicial circuit, its jurisdiction differs from that of the generalist, regional circuits in that it is defined by subject matter rather than by geography, and, in general, it is exclusive rather than concurrent. ${ }^{66}$

Courts of limited, exclusive jurisdiction have been relatively

64 See Federal Court Improvement Act of 1982, Pub. L. No. 97-164, § 127(a), 96 Stat. 25, 37-38 (codified at 28 U.S.C. $\$ \S 1295(a)(1),(4)(C)(1982)$ ).

For further discussion of this jurisdiction, see infra text accompanying notes 92 93; Christianson v. Colt Indus. Operating Corp., 486 U.S. 800 (1988); Dreyfuss, supra note 13 , at $30-37$.

65 In addition to patents, the Federal Circuit inherited the jurisdiction of the Court of Customs and Patent Appeals over appeals from the PTO with respect to applications for registration of trademarks, see 28 U.S.C. \$ $1295(\mathrm{a})(4)(\mathrm{B})$ (1982); appeals from the Court of International Trade, see id. $\$ 1295(a)(5)$; review of final determinations of the International Trade Commission relating to unfair import trade practices, see id. $\S 1295$ (a)(6), review of findings by the Secretary of Commerce relating to the duty-free import of unique scientific apparatus for educational purposes, see id. § 1295(a)(7); and appeals under the Plant Variety Protection Act, see id. $\S 1295(\mathrm{a})(8)$.

The Federal Circuit's jurisdiction with respect to trademarks, however, is not exclusive, as it does not extend beyond the jurisdiction previously exercised by the Court of Customs and Patent Appeals. An individual denied registration of a mark by the PTO can bring a civil action in district court as an alternative to review in the Federal Circuit. Moreover, the Federal Court Improvement Act did not vest the Federal Circuit with jurisdiction over appeals in infringement cases, as it did for patents.

The Act also augmented the inherited jurisdiction of the Federal Circuit by granting it exclusive jurisdiction over appeals from most final orders and decisions of the Merit Systems Protection Board. See id. $\$ 1295(\mathrm{a})(9)$. In addition, in 1988, Congress vested in the Federal Circuit exclusive jurisdiction to review decisions of the newly created Court of Veterans Appeals. See Veterans' Judicial Review Act of 1988, Pub. L. No. 100-687, § 301, 102 Stat. 4105,4120 (to be codified at 38 U.S.C. $\S 4092)$.

As indicated above, the Federal Circuit also inherited the jurisdiction of the Court of Claims. See supra note 2. It has exclusive jurisdiction over appeals from the Claims Court, see 28 U.S.C. $\$ 1295$ (a)(3) (1982), which was created out of the trial level of the Court of Claims, see S. REP. No. 275, supra note 2, at 4, reprinted in 1982 U.S. Code Cong. \& Admin. News at 14; Miller, The New United States Claims Court, 32 Clev. St. L. Rev. 7, 8 (1983-84). Appeals from final determination of agency boards of contract appeals under the Contracts Dispute Act of 1978, see Pub. L. No. 95-563, 92 Stat. 2383 (codified at 42 U.S.C. $\$ \S 601-13$ (1982)), are likewise taken to the Federal Circuit. See 28 U.S.C. $\$ \S 1295(a)(10)$, (b), (c) (1982). The Federal Circuit also has exclusive jurisdiction over appeals from all federal district courts in civil actions against the United States for $\$ 10,000$ or less (not founded upon tort or tax claims). See 28 U.S.C. \$§ 1295(a)(2), 1346 (1982).

66 See S. ReP. No. 275, supra note 2, at 3, reprinted in 1982 U.S. Code Conc. \& Admin. News at 13; Adams, supra note 62, at 44; Markey, The Court of Appeals for the Federal Circuit: Challenge and Opportunity, 34 AM. U.L. Rev. 595, 599 (1985). Among 
common. For example, Congress established the Commerce Court in 1910 and vested it with exclusive jurisdiction over suits seeking to enforce or to set aside orders of the ICC. ${ }^{67}$ The Commerce Court was thus given the politically sensitive task of determining the appropriate rates for railroads to charge shippers. ${ }^{68}$ The court was abolished in 1913 in the face of great controversy over the manner it carried out its functions. ${ }^{69}$

Economic crises have led to the creation of two other courts of this type. As part of a comprehensive system of price controls imposed during World War II pursuant to the Emergency Price Control Act of $1942,{ }^{70}$ Congress established the Emergency Court of

the regional courts, however, the D.C. Circuit does have exclusive jurisdiction over various subject matters. See supra text accompanying notes 52-54.

67 See Act of June 18, 1910, ch. 309, 36 Stat. 539, 539-42; see also F. Frankfurter \& J. LANDIS, supra note 61, at 153-62. The Commerce Court's jurisdiction did not extend to criminal proceedings. See Act of June 18, 1910, ch. 309, 36 Stat. 539, 539 40.

68 See F. Frankfurter \& J. Landis, supra note 61, at 162-66. Soon after commencing operation, the Commerce Court reversed many ICC decisions in favor of shippers, see id. at $167 \mathrm{n} .105$, and was itself reversed on many of these decisions by the Supreme Court, see id. at 164-65. During its first two years, the Commerce Court was reversed in nine of the eleven cases that reached the Supreme Court. See Rightmire, supra note 56 , at 112 . By the time the Commerce Court was abolished, it had been reversed in 13 of 22 cases. See Nathanson, supra note 11, at 1006. The court was heavily criticized as biased in favor of the railroads, as its opponents had predicted. See F. FRANKFurTer \& J. LANDIs, supra note 61, at 166-68; Nathanson, supra note 11 , at 1005 .

The charge of bias, however, may have been unfounded:

[T] he Commerce Court entered an environment partial to the Commission and distrustful of courts. With undoubted courage and disinterestedness the Court, heedless of the public temper, promptly began to reverse the Commission and to curb its activity. But its legal wisdom was not equal to its indifference to popular sentiment.

F. Frankfurter \& J. LANDis, supra note 61 , at 165.

69 See Act of Oct. 22, 1913, ch. 32, 38 Stat. 208, 219. Congress provided that the tenure of the judges would not be affected, and that they would be assigned to sit as district court or circuit court judges, but that no successors to these judges would be appointed. Earlier versions of the legislation, however, had sought to abolish the judgeships as well as the court. See F. FrankfurTER \& J. Landis, supra note 61 , at 168-73.

For in-depth accounts of the rise and fall of the Commerce Court, see id. at 15373; Dix, The Death of the Commerce Court: A Study in Institutional Weakness, 8 Am. J. LegaL HIST. 238 (1964); Rightmire, supra note 56. The experience of Commerce Court is reviewed in almost every survey of specialized federal courts. See, e.g., H. Friendly, supra note 13, at 153-54; Jordan, supra note 13, at 762-65; Nathanson, supra note 11 , at 1004-08.

70 Emergency Price Control Act of 1942, ch. 26, 56 Stat. 23. For academic commentary, see Freund, The Emergency Price Control Act of 1942: Constitutional Issues, 9 Law \& Contemp. Probs. 77 (1942); Ginsburg, The Emergency Price Control Act of 1942: 
Appeals. ${ }^{71}$ Congress provided that regulations, orders, and price schedules of the Office of Price Administration (OPA) could be challenged only within thirty days and only in the Emergency Court of Appeals. ${ }^{72}$ The statute provided that "no court, Federal, State, or Territorial," would have jurisdiction to review such decisions. ${ }^{73}$ In Yakus $v$. United States, ${ }^{74}$ the Supreme Court held that, as a result of this proscription, the validity of an OPA regulation could not even be attacked as a defense in a criminal proceeding. ${ }^{75}$

Similarly, in 1971, Congress established the Temporary Emergency Court of Appeals, ${ }^{76}$ to adjudicate disputes concerning the Economic Stabilization Act of $1970,{ }^{77}$ which gave the President authority, in light of spiraling inflation, to impose emergency controls on prices, rents, wages, and salaries. ${ }^{78}$ Congress vested the court with exclusive jurisdiction over appeals from district court decisions "in cases and controversies arising under this [Act] or under regulations or orders issued thereunder." 79 In addition, district courts were instructed to certify to the Temporary Emergency Court of Appeals any "substantial constitutional issue[s]."

Basic Authority and Sanctions, 9 LAW \& Contemp. Probs. 22 (1942); Nathanson, The Emergency Price Control Act of 1942: Administrative Procedure and Judicial Review, 9 LAw \& Contemp. Probs. 60 (1942).

71 See Emergency Price Control Act of 1942, ch. 26, § 204(c), 56 Stat. 23, 32.

72 See id. § 204(a), 56 Stat. at \$1. The court's jurisdiction was enlarged over the years to include review of administrative decisions under the Housing and Rent Act of 1948, ch. 161, 62 Stat. 93, 97; the Housing and Rent Act of 1949, ch. 42, 63 Stat. 18, 23; and the Defense Production Act of 1950, ch. 932, § 408, 64 Stat. 798, 809.

73 Emergency Price Control A.ct of 1942, ch. 26, § 204(d), 56 Stat. 23, 33. For discussion of the jurisdiction of the Emergency Court of Appeals, see Yakus v. United States, 321 U.S. 414, 427-31 (1944); Lockerty v. Phillips, 319 U.S. 182 (1943).

74321 U.S. 414 (1944).

75 See id. at 443-48. Many federal environmental statutes are modeled after the review scheme upheld in Yakus. They provide that regulations by the Environmental Protection Agency (EPA) can be challenged only in the D.C. Circuit within a short time after their promulgation, and that the validity of such regulations cannot be litigated subsequently in civil or criminal enforcement proceedings. See, e.g., 33 U.S.C. § 1369(b) (1982) (Clean Water Act); 42 U.S.C. § 300j-7(a) (1982) (Safe Drinking Water Act); 42 U.S.C. $\$ 7607$ (b) (1982) (Clean Air Act); 42 U.S.C. § 9613(a) (1982) (Comprehensive Environmental Response, Compensation and Liability Act); Adamo Wrecking Co. v. United States, 434 U.S. 275, 285 (1978) (Clean Air Act).

76 See Economic Stabilization Act Amendments of 1971, Pub. L. No. 92-210, $\S 211$ (b)(1)-(2), 85 Stat. 743, 749 iexpired 1974).

77 See Economic Stabilization Act of 1970, Pub. L. No. 91-379, §§ 201-206, 84

Stat. 796, 799-800 (expired 1974).

78 See id. \& 202, 84 Stat. at 799-800.

79 Economic Stabilization Act Amendments of 1971, Pub. L. No. 92-210, $\S 211$ (b)(2), 85 Stat. 743, 749 (expired 1974).

80 Id. $\$ 211(\mathrm{c}), 85$ Stat. at 749 . In such cases, the Temporary Emergency Court 
This control scheme expired in $1974,{ }^{81}$ but the Temporary Emergency Court of Appeals survived as a result of another economic emergency. In 1973, at the height of the energy crisis, Congress enacted the Emergency Petroleum Allocation Act, ${ }^{82}$ which gave the President temporary authority to deal with shortages of crude oil, fuel oil, and refined petroleum products. ${ }^{83}$ This statute incorporated the provisions of the Economic Stabilization Act for judicial review by the Temporary Emergency Court of Appeals. ${ }^{84}$ The court is still in existence. ${ }^{85}$

My definition of courts of limited, exclusive jurisdiction ${ }^{86}$ includes courts which might not hear every case raising a particular issue. For example, the Supreme Court has interpreted the patent jurisdiction of the Federal Circuit to extend only to cases in which the patent claim appears on the face of a "well-pleaded complaint." 87 Thus, a case that raises only antitrust and tort violations in the complaint must be appealed to a regional circuit even though the litigation in the district court had focused on questions of patent law. ${ }^{88}$ As a result, many cases that involve significant patent issuesfor example, disputes over licensing agreements-do not fall within the jurisdiction of the Federal Circuit. ${ }^{89}$ But even under the "wellpleaded complaint" rule, the specialized court will be the principal actor, and other courts will play a secondary role.

I also assume that a court's jurisdiction is limited even if, in fact, the court adjudicates issues outside the subject matter of its jurisdiction. Limited jurisdiction can take one of two forms. Under limited "issue" jurisdiction, a court decides only the issues within its subject matter jurisdiction, not the entire case. The Emergency Court of Appeals and the Temporary Emergency Court of Appeals are exam-

of Appeals could either determine the entire action or decide the certified issue and remand the action to the district court. See id.

81 See Economic Stabilization Act Amendments of 1973, Pub. L. No. 93-28, $\S 218,87$ Stat. 27, 29 (expired 1974).

82 Emergency Petroleum Allocation Act of 1973, Pub. L. No. 93-159, 87 Stat.

627 (codified as amended at 15 U.S.C. $\$ \$ 751-60 \mathrm{~h}(1988)$ ).

83 See id. $\S 2(\mathrm{~b}), 87$ Stat. at 628.

84 See Emergency Petroleum Allocation Act of 1973, Pub. L. No. 93-159, $\S 5(a)(1), 87$ Stat. 627,633 (codified at 15 U.S.C. $\$ 754$ (a)(1) (1988)).

85 See Elkins, The Temporary Emergency Court of Appeals: $A$ Study in the Abdication of Judicial Responsibility, 1978 Duke L.J. 113, 118 n.17; Comment, The Appellate Jurisdiction of the Temporary Emergency Court of Appeals, 64 MinN. L. REv. 1247, 1247 n.2 (1980).

86 Other bodies in this category, such as the Court of Veterans Appeals and various adjudicatory agencies, are discussed infra text accompanying notes 112-27.

87 Christianson v. Colt Indus. Operating Corp., 486 U.S. 800, 809 (1988).

88 See id. at 810-11; Dreyfuss, supra note 13, at 32 .

89 See Dreyfuss, supra note 13 , at 34 n.203. 
ples of specialized courts with issue jurisdiction. The former had jurisdiction only over pre-enforcement challenges to regulations and orders; enforcement actions were brought in the district court and appealed to the generalist courts of appeals. ${ }^{90}$ The latter has jurisdiction over appeals from the district courts in both pre-enforcement and enforcement cases, but only with respect to the issues within its subject matter jurisdiction. Other issues are appealed to the generalist circuit courts, creating a bifurcated appellate structure. ${ }^{91}$

In contrast, under limited "case" jurisdiction, a court decides the entire case, for all cases that present an issue within its subject matter jurisdiction. The Federal Circuit has adopted case jurisdiction with respect to patent appeals, although for non-patent issues it applies the case law of the court of appeals that would have heard the case if it had not come within the scope of the Federal Circuit's exclusive jurisdiction. ${ }^{92}$ However, even a court that exercises case jurisdiction is unlikely to be an important actor on issues outside its subject matter jurisdiction, and therefore it is appropriate to treat it as a court of limited jurisdiction. ${ }^{93}$

\section{B. The Staffing of Courts of Limited Jurisdiction}

Perhaps the most basic choice that must be made in creating a court of limited jurisdiction is whether to staff it with specialized or generalist judges. The former would hear only cases within the limited jurisdiction of the specialized court. The latter would be judges who regularly sit in the district or the regional circuits courts. ${ }^{94}$

Examples of the former are the Federal Circuit, the Court of

90 The petitioners in Yakus, for example, were convicted in the District of Massachusetts; their convictions were upheld by the First Circuit. See Yakus v. United States, 321 U.S. 414, 418-19 (194.4).

91 See Coastal States Mktg. v. New England Petroleum Corp., 604 F.2d 179, $182-$ 86 (2d Cir. 1979); see also Atlantic Richfield Co. v. U.S. Department of Energy, 769 F.2d 771, 779-80 (D.C. Cir. 1984); Mobil Oil Corp. v. Tully, 639 F.2d 912, 914-17 (2d Cir. 1981), cert. denied, 452 U.S. 967 (1981); Comment, supra note 85, at 1250-62.

92 See Atari, Inc. v. JS \& A Group, Inc., 747 F.2d 1422, 1436-41 (Fed. Cir. 1984); Panduit Corp. v. All States Plastic Mfg. Co., 744 F.2d 1564, 1573-76 (Fed. Cir. 1984) (per curiam); Dreyfuss, supra note 13, at 37-46.

93 This effect is particularly pronounced where, as to those issues, the specialized court simply follows the case law of the generalist courts, similar to the Federal Circuit.

94 This inquiry need not be performed for courts that are specialized as a result of their exclusive jurisdiction over a particular subject matter, but that have unlimited jurisdiction. By definition, as a result of the unlimited jurisdiction, the judges who serve on such courts are generalist judges. Among the existing courts, only the D.C. Circuit belongs to this category. See supra text accompanying notes 52-54. 
International Trade, the Tax Court, ${ }^{95}$ the Court of Veterans Appeals, ${ }^{96}$ and certain adjudicatory agencies, which as I explain in the following section, should be regarded as functional analogues of specialized courts. ${ }^{97}$ The first two of these courts are Article III courts and its judges can be assigned to sit by designation on the generalist Article III courts. ${ }^{98}$ While judges who avail themselves of

95 When the Board of Tax Appeals, the predecessor of the Tax Court, see supra note 9, was established in 1924, it was staffed by seven members appointed by the President with the advice and consent of the Senate, for ten-year terms, and removable, for cause, by the President. See Revenue Act of 1924, ch. 234, $\$ 900$ (a)(b), 43 Stat. 253, 336-37. But for its first two years, the Board was authorized to have up to 28 members in order to reduce the backlog of cases. See id. However, only 16 members were actually appointed. See H. DuBRofF, supra note 9, at 84 .

The term of office of the judges was later extended to twelve years, see Revenue Act of 1926, ch. 27, § 901(b), 44 Stat. 9, 106; see also id. §900, 44 Stat. at 105-06 (changing to 16 the number of authorized judgeships), and then fifteen years. See Tax Reform Act of 1969, § 952(e), 83 Stat. 487, 730.

96 The court will have between three and seven judges appointed for fifteenyear terms by the President with the advice and consent of the Senate. See Veterans' Judicial Review Act of 1988, Pub. L. No. 100-687, § 301 (a), 102 Stat. 4105, 4114 (to be codified at 38 U.S.C. $\$ 4053(\mathrm{a})$-(b)). The judges will be removable only for cause. See id. § 301 (a), 102 Stat. at 4114 (to be codified at 38 U.S.C. $\S 4053(\mathrm{f})$ ). The legislation became effective on September 1, 1989, but it provided that the court would not commence operation until at least three judges had been appointed. See id. $\S 401,102$ Stat. at 4122 (to be codified at 38 U.S.C. $\S 4051$ note).

97 See infra text accompanying notes 115-25.

The Court of Customs and Patent Appeals and its predecessor, the Court of Customs Appeals, were also staffed by specialized judges. Congress established the Court of Customs Appeals in 1909, and provided that the court would consist of five judges appointed by the President wits the advice and consent of the Senate; the statute did not specify the judges' tenure or the conditions for their removal. See Tariff Act of 1909, ch. 6, § 29, 36 Stat. 11, 105. In 1929, Congress extended the jurisdiction of the Court of Customs Appeals and renamed it the Court of Customs and Patent Appeals. See Act of Mar. 2, 1929, ch. 488, §§ 2-3, 45 Stat. 1475, 1475-76.

98 See 28 U.S.C. § 291 (1982) (Federal Circuit); id. § 293 (Court of International Trade).

The route to Article III status was not a direct one. In 1929, the Supreme Court held that the Court of Customs and Patent Appeals (the predecessor to the Federal Circuit, see supra note 2, was an Article I court rather than an Article III court. See Ex parte Bakelite Corp., 279 U.S. 438, 460 (1929); see also Williams v. United States, 289 U.S. 553, 581 (1933) (holding that the Court of Claims was not an Article III court).

In 1956, Congress enacted legislation declaring that the Customs Court (the predecessor to the Court of International Trade) and the Court of Customs and Patent Appeals were Article III courts. See Act of July 14, 1956, ch. 589, 70 Stat. 532, 532 (Customs Court); Act of Aug. 25, 1958, 72 Stat. 848, 848 (Court of Customs and Patent Appeals). Similarly, three years earlier, Congress had declared the Court of Claims to be an Article III court. See Act of July 28, 1953, ch. 253, 67 Stat. 226, 226. An explicit reason for these declarations was to permit judges on these specialized courts to sit on the district courts and courts of appeals, and to allow judges on those courts to reciprocate. See Act of Aug. 25, 1958, $\$$ 2-4, 72 Stat. at 848-49; H.R. REP. No. 695, 83rd Cong., 1st Sess. 2, reprinted in 5 Congress AND the Courts: A 
this opportunity will encounter, at least occasionally, the caseload of a generalist judge, such opportunities are too infrequent to merit the classification of such judges as generalist.

Even among specialized judges, it is appropriate to make distinctions based on the extent to which their jurisdiction is limited. Judges on the Federal Circuit, for example, review the decisions of various agencies. ${ }^{99}$ In contrast, judges on the Tax Court and the Court of Veterans Appeals review the decisions of a single agency. ${ }^{100}$

With respect to generalist judges sitting on specialized courts, the assignment can either be part-time, where the judge continues to serve on her generalist court, or full-time for a temporary period, in which the judge returns to the generalist court after service in the specialized court. For example, both the Emergency Court of Appeals and the Temporary Emergency Court of Appeals were staffed by three or more district or circuit judges selected by the Chief Justice of the United Sitates to serve on a part-time basis. ${ }^{101}$ In general, this method of staffing has been used for subject-matter categories in which uniformity is important and there is a relatively small volume of cases. ${ }^{102}$

The full-time assignment of generalist judges to specialized courts for a temporary period is less common. The legislation that established the Commerce Court provided that it would be staffed by

Legislative History, 1787-1977, at 17,938, 17,939 (B. Reams \& C. Haworth eds. 1978) [hereinafter CoNGRess AND THE CouRTS].

In Glidden Co. v. Zdanok, 370 U.S. 530 (1962), the Supreme Court dispelled doubts about the effectiveness of this declaration. See H.R. REP. No. 2349, 85th Cong., 2d Sess. 6, reprinted in Congress AND THE CourTs, supra, at 18,167 (Judicial Conference of the United States declined to express an opinion). Overruling Ex parte Bakelite Corp., the Supreme Court held that, in view of the congressional designation of Article III status, the Court of Customs and Patent Appeals was an Article III court. See Glidden Co., 370 U.S. at 584. The Court also held that the Court of Claims was an Article III court, see id., but did not decide the status of the Customs Court.

99 See supra text accompanying notes 63-66.

100 See supra text accompanying notes 9-10.

101 The composition of the Emergency Court of Appeals is set forth in Emergency Price Control Act of 1942, ch. 26, $\$ 204(c), 56$ Stat. 23, 32; see Carrington, supra note 42, at 605. Between 1943 and 1945, however, the judges worked almost full-time on the Emergency Court of Appeals. See Nathanson, supra note 11 , at 1010. Throughout the years, the membership of the court fluctuated between three and five. See Transcript of Proceedings of the Final Session of the Court, 299 F.2d 1, 15-16 (1961).

The composition of the Temporary Emergency Court of Appeals is set forth in Economic Stabilization Act Amendments of 1971, Pub. L. No. 92-210, § 211(b)(1), 85 Stat. 743, 749 (expired 1974). Currently, the court has twelve judges. See Judges of the Federal Courts, 872 F.2d vii, xxxii (1989).

102 See P. Carrington, D. Mjeador \& M. Rosenberg, supra note 48, at 170-72. 
five judges selected from among sitting federal circuit judges by the Chief Justice of the United States; these judges would serve on the Commerce Court for five years before returning to their circuit court positions. ${ }^{103}$ The first group of judges, however, consisted of newly appointed circuit judges, designated to serve initially on the Commerce Court. ${ }^{104}$

\section{Hierarchical Relationship Between Courts Staffed by Specialized Judges and Generalist Courts}

The final element of a taxonomy of specialization concerns the relationship of courts staffed by specialized judges to the generalist judges in the federal system. For this Article, one distinction is crucial: whether the highest level of specialized adjudication under a particular administrative scheme supplants the reviewing function of the generalist, regional circuits, or instead is subordinate to the generalist, regional courts.

The D.C. Circuit, the Federal Circuit, and the Temporary Emergency Court of Appeals belong to the category of specialized courts that are not subject to review by the generalist, regional circuits. Rather, as with the regional circuits, decisions of these courts are subject to review only by the Supreme Court. The absence of review by the regional, generalist courts of appeals also characterized the Commerce Court, ${ }^{105}$ the Court of Customs and Patent Appeals, ${ }^{106}$ and the Emergency Court of Appeals, ${ }^{107}$ as well as the proposed Court of Tax Appeals. ${ }^{108}$

103 See Act of June 18, 1910, ch. 309, 36 Stat. 539, 540. There was a bar against a judge sitting on the court for two consecutive terms. See id. The legislation thus ensured that the Commerce Court would be staffed by generalist judges serving temporary rotations on the court.

104 See id.

105 See Act of June 18, 1910, ch. 309, § 2, 36 Stat. 539, 542.

106 Initially, the Court of Customs Appeals was exempt altogether from Supreme Court review. See Tariff Act of 1909, ch. 6, § 29, 36 Stat. 11, 106. Congress amended the statute in 1914, primarily to allow for Supreme Court review of constitutional and treaty questions. See Act of Aug. 22, 1914, ch. 267, 38 Stat. 703. In addition, review was available "in any other case when the Attorney General of the United States shall, before the decision of the Court of Customs Appeals is rendered, file with the court a certificate to the effect that the case is of such importance as to render expedient its review by the Supreme Court." Id. These limitations on review by the Supreme Court were repealed in 1930, one year after the Court of Customs Appeals was renamed as the Court of Customs and Patent Appeals, see supra text accompanying note 61. See Tariff Act of 1930, ch. 497, § 647, 46 Stat. 590, 762.

107 See Emergency Price Control Act of 1942, ch. 26, § 204(d), 56 Stat. 23, 32.

108 See Griswold, supra note 20, at 1164-66. In fact, one proposal for a Court of Tax Appeals contemplated that the decisions of this court would be subject to 
This first category also contains two courts that are subject to intermediate appellate review-the Court of International Trade and the Court of Veterans Appeals-because this review occurs in a court of limited jurisdiction. The Court of International Trade has exclusive jurisdiction over the review of administrative decisions on the classification of goods and the setting of tariffs; it also has jurisdiction over certain cases dealing with countervailing duties and nontariff trade barriers. ${ }^{109}$ Decisions of the Court of International Trade can be appealed to the Federal Circuit. ${ }^{110}$

The Court of Veterans Appeals has exclusive jurisdiction to review decisions of the Veterans' Administration denying benefits to claimants. ${ }^{11}$ The decisions of the Court of Veterans Appeals, in turn, can be appealed to the Federal Circuit, ${ }^{112}$ but the scope of this review is quite limited. A party can seek review, as of right, on the validity or interpretation of a statute or regulation. The Federal Circuit, however, may not review factual determinations or applications of the statute and regulations to the facts of a particular case, except where the appeal presents a constitutional issue. ${ }^{13}$

In contrast, the decisions of some specialized courts are subject to appellate review by the regional circuits. The Tax Court's decisions, for example, are subject to review in the circuit in which the taxpayer resides. Until recently, this hierarchical relationship was somewhat muddled by the Tax Court's refusal to follow the case law of the court of appeals with venue to review a particular decision. Since 1970, however, the Tax Court follows the case law of the court of appeals that will review its decision, whenever the identity of this court is easily ascertainable. ${ }^{114}$

In addition, I place in this category various adjudicatory bodies that are not generally treated as courts. For example, in the 1970s, Congress created several exclusively adjudicatory agencies to review administrative determinations. Two prominent examples are the

Supreme Court review only with respect to constitutional questions. See H. FriendLY, supra note 13, at 167-68.

109 See supra note 3.

110 See 28 U.S.C. $\$ 1295$ (a)(5) (1982).

11 See Veterans' Judicial Review Act of 1988, Pub. L. No. 100-687, § 301(a), 102 Stat. 4105,4113 (to be codified at 38 U.S.C. $\$ 4052$ ).

112 See id. $\S 301$ (a), 102 Stat. at $4120-21$ (to be codified at 38 U.S.C. $\S 4092$ ). The judgment of the Federal Circuit is reviewable by the Supreme Court on certiorari. See id. $\S 301$ (a), 102 Stat. at 4120 (to be codified at 38 U.S.C. $\S 4092$ (c)). 113 See id. $\S 301$ (a), 102 Stat. at 4121 (to be codified at 38 U.S.C. $\S 4092(d)(2)$ ). 114 See supra note 59. 
Occupational Safety and Health Review Commission (OSHRC) ${ }^{115}$ and the Federal Mine Safety and Health Review Commission (FMSHRC). ${ }^{116}$

OSHRC's function is to determine whether regulations promulgated and enforced by the Occupational Safety and Health Administration (OSHA) have been violated. ${ }^{117}$ Similarly, FMSHRC adjudicates violations of standards promulgated and enforced by the Mine Safety and Health Administration (FMSHA). ${ }^{118}$ Decisions of OSHRC and FMSHRC are reviewable in the regional courts of appeals, although under venue-uncertain provisions. ${ }^{119}$

While both OSHA and FMSHA are agencies within the Department of Labor, OSHRC and FMSHRC are independent agencies whose members-three for OSHRC and five for FMSHRC-are appointed by the President with the advice and consent of the Senate, serve six-year terms, and may be removed only for inefficiency, neglect of duty, or malfeasance in office. ${ }^{120}$ Commentators have referred to this separation of adjudicatory functions from rulemaking and enforcement functions as a "split-enforcement" model. ${ }^{121}$

OSHRC and FMSHRC are purely adjudicatory bodies; they have no rulemaking or enforcement powers. ${ }^{122}$ They are functionally no

115 OSHRC was established by the Occupational Safety and Health Act of 1970 , Pub. L. No. 91-596, § 12, 84 Stat. 1590, 1603 (codified as amended at 29 U.S.C. $\S 661$ (1982)).

116 FMSHRC was established by the Federal Mine Safety and Health Amendments Act of 1977, Pub. L. No. 95-164, § 113, 91 Stat. 1290, 1313 (codified at 30 U.S.C. $\S 823$ (1982)).

117 See 29 U.S.C. § 659 (1982).

118 See 30 U.S.C. $\$ 815$ (1982).

119 Any person aggrieved by a final order of OSHRC can obtain review in the court of appeals where the violation is alleged to have occurred, where the employer has its "principal office," or in the D.C. Circuit. See 29 U.S.C. \$660(a) (1982). Decisions of FMSHRC can be appealed in the court of appeals in which the violation occurred, or in the D.C. Circuit. See 30 U.S.C. $\$ 816$ (a) (1982). For a discussion of the relationship between OSHRC and the courts of appeals, see Estreicher \& Revesz, supra note 15 , at 714-15.

120 See Occupational Safety and Health Act of 1970, Pub. L. No. 91-596, § 12, 84 Stat. 1590, 1603-04 (codified as amended at 29 U.S.C. $\$ 661$ (1982)) (OSHRC); Federal Mine Safety and Health Amendments Act of 1977, Pub. L. No. 95-164, $\S 113,91$ Stat. 1290,1313 (codified at 30 U.S.C. § 823 (1982)) (FMSHRC).

121 See, e.g., Johnson, supra note 41, at 294; Verkuil, The Purposes and Limits of Independent Agencies, 1988 DuKE L.J. 257, 268-69.

122 See 29 U.S.C. § 661 (1982) (OSHRC); 30 U.S.C. § 823 (1982) (FMSHRC).

Agencies with similar characteristics include the Merit Systems Protection Board (MSPB), which reviews removals and demotions of federal employees, see 5 U.S.C. $\S \S 1201-1209$ (1982), and the National Transportation Safety Board (NTSB), which 
different from a court such as the Tax Court, which determines whether regulations promulgated by the IRS have been violated.

This Article concerns adjudications undertaken to review administrative action, rather about adjudications that serve as a vehicle for administrative agencies to develop policy. Consequently, for OSHRC and FMSHRC to fall within the former category and therefore to be proper subjects for this study, they cannot be the primary policymakers under their respective statutes, and their interpretations of these statutes cannot be accorded the deference that accompanies policymaking authority. ${ }^{123}$ Instead, OSHA and FMSHA, the regulatory/enforcement agencies, must be treated as the primary policymakers. The courts have recognized that FMSHA rather than FMSHRC is the primary policymaker entitled to deference, ${ }^{124}$ but have split on whether the same relationship holds between OSHA and OSHRC. ${ }^{125}$

reviews certain license revocation actions by the Secretary of Transportation and the Commandant of the Coast Guard, see 49 U.S.C. $\$ 903(\mathrm{a})(9)$ (1982).

Unlike OSHRC and FMSHRC, these two agencies have some non-adjudicatory powers. The MSPB conducts studies relating to the civil service and makes legislative recommendations to Congress and the President, see 5 U.S.C. $\$ \S 1205(a)(3)$, (k) (1982), whereas the NTSB conducts accident investigations and formulates safety improvement recommendations. See 49 U.S.C. \$§ 1901, 1903(a)(1)-(8) (1982).

123 See Chevron, U.S.A v. National Resources Defense Council, 467 U.S. 837 (1984).

124 See Secretary of Labor v. Cannelton Indus., 867 F.2d 1432, 1435 (D.C. Cir. 1989) ("When the Secretary [of Labor] and the Commission divide, it . . a appears that the Secretary rather than the Commission is entitled to ... deference." (citations omitted)); S. REP. No. 181, 95th Cong., lst Sess. 49 (1977), reprinted in 1977 U.S. Code Cong. \& Admin. News 3401, 3448 ("Since the Secretary of Labor is charged with responsibility for implementing [the Federal Mine Safety and Health Act of 1977], it is the intention of the Committee, consistent with generally accepted precedent, that the Secretary's interpretations of the law and regulations shall be given weight by both [FMSHRC] and the courts."); Johnson, supra note 41, at 325-29.

125 This split is evident in cases concerning a dispute between the head of OSHA-the Secretary of Labor--and OSHRC. Compare Brock v. Schwarz-Jordan, Inc., 777 F.2d 195, 197 (5th Cir. 1985) ("We have chosen to adopt a somewhat different approach to the respective roles of the Secretary and the Commission'... . The Secretary's interpretation 'is controlling as long as it is one of several reasonable interpretations . ..." (citations omitted)) and Donovan v. Amorello \& Sons, Inc., 761 F.2d 61, 65 (1st Cir. 1985) ("After examining the relevant statutes and their legislative history, we side with those circuits that favor the Secretary's [reasonable] ... interpretation in disputes with the Commission. ...") with Brock v. Bechtel Power Corp., 803 F.2d 999, 1000 (9th Cir. 1986) ("[A]lthough we have recognized that the Secretary's interpretation of his own regulation . . . must be accorded substantial weight, it carries much less weight when at odds with the Commission." (citations omitted)) and Brennan v. OSHRC, 513 F.2d 713, 715-16 (8th Cir. 1975) ("While the Secretary may have intended the regulation to mean one thing, it is the Commission and not the Secretary which is charged with the final administrative adjudication of the Act."). For discussions of the split, see Johnson, supra note 41, at 304-25; 
Finally, straddling the two categories described in this section, there are possible hybrids, in which there is only limited review of the decisions of the specialized court in the generalist courts of appeals. For example, Justice Scalia has suggested the creation of a specialized court to review decisions of the Social Security Administration, which would be subject only to certiorari review on questions of law by the courts of appeals. ${ }^{126}$

\section{Classification of the Existing Specialized Courts}

Table II presents a classification, by reference to this taxonomy, of the specialized courts charged with the review of administrative action that are now in existence as well as courts that were once in existence but were subsequently abolished. It indicates, first, whether the jurisdiction of the court is unlimited, exclusive; limited, non-exclusive; or limited, exclusive. ${ }^{127}$ Second, it shows whether the court is staffed by specialized or generalist judges. Third, it indicates whether the decisions of the court are subject to review in the generalist, regional circuits.

The courts in Table II fall into six different categories. These categories, and the courts falling in each, are indicated in Table III.

Shapiro \& McGarity, Reorienting OSHA: Regulatory Alternatives and Legislative Reform, 6 YALE J. ON REG. 1, 59-62 (1989).

Whereas the legislative history delineates the respective responsibilities of FMSHA and FMSHRC, see supra note 124, it does not contain any statement about the proper recipient of deference in the OSHA/OSHRC context. See Johnson, supra note 41 , at 303-04.

To avoid the problem of uncertainty as to which agency is due deference, the Administrative Conference of the United States has recommended that " $[w]$ here Congress establishes an enforcement scheme in which rulemaking and prosecution are assigned to one agency and adjudication to another agency, it should make clear in which agency it intends to place programmatic responsibility and direct the courts to look to that agency for authoritative expressions of law or policy." Admin. Conf. of the U.S., The Split-Enforcement Model for Agency Adjudication, 1 C.F.R. $\$ 305.86-4$ (1989).

126 See Remarks by Justice Antonin Scalia, supra note 44, at 10; see also H.R. 3865, 97th Cong., Ist Sess. (1981) (establishing a Social Security Court that would have made the decisions of this court appealable to the D.C. Circuit only with respect to statutory and constitutional questions); supra text accompanying notes 111-13 (setting forth the limited scope of review of decisions of the Court of Veterans Appeals).

127 As stated above, courts of unlimited, non-exclusive jurisdiction are generalist courts. See supra text accompanying notes 49-50. 
Table II: Classification of Specialized Courts

\begin{tabular}{l|l|l|l}
\hline Court* & \multicolumn{1}{|c|}{ Jurisdiction } & Staffing & $\begin{array}{c}\text { Generalist } \\
\text { Circuit } \\
\text { Review }\end{array}$ \\
\hline CIT & Limited, Exclusive & Specialized & No \\
CCPA & Limited, Non-Exclusive & Specialized & No \\
Commerce & Limited, Exclusive & Generalist & No \\
Tax & Limited, Non-Exclusive & Specialized & Yes \\
ECA & Limited, Exclusive & Generalist & No \\
TECA & Limited, Exclusive & Generalist & No \\
GAFC & Limited, Exclusive & Specialized & No \\
GVA & Limited, Exclusive & Specialized & No \\
OSHRC & Limited, Exclusive & Specialized & Yes \\
FMSHRC & Limited, Exclusive & Specialized & Yes \\
CADC & Unlimited, Exclusive & Generalist & No \\
Claims & Limited, Non-Exclusive & Specialized & No** \\
\hline
\end{tabular}

* The following abbreviations are used in this Table: Court of International Trade (CIT), Court of Customs and Patent Appeals (CCPA), Emergency Court of Appeals (ECA), Temporary Emergency Couirt of Appeals (TECA), Federal Circuit (CAFC), Occupational Safety and Health Review Commission (OSHRC), Federal Mine Safety and Health Review Commission (FMSHRC), and D.C. Circuit (CADC).

** The Claims Court is classified only by reference to its jurisdiction over tax cases.

Table III: Types of Specialized Courts

\begin{tabular}{|c|c|c|c|c|}
\hline Type & Jurisdiction & Staffing & $\begin{array}{c}\text { Generalist } \\
\text { Circuit } \\
\text { Review }\end{array}$ & Courts* \\
\hline I & unlimited, exclusive & generalist & no & CADC \\
\hline II & limited, non-exclusive & specialized & yes & Tax \\
\hline III & limited, non-exclusive & specialized & no & CCPA, Claims \\
\hline IV & limited, exclusive & generalist & no & Commerce, ECA, TECA \\
\hline $\mathrm{V}$ & limited, exclusive & specialized & yes & OSHRC, FMSHRC \\
\hline VI & limited, exclusive & specialized & no & CAFC, CVA, CIT \\
\hline
\end{tabular}

* The abbreviations are the same as those used in Table II. 


\section{Specialized Courts and the Delegation of Legislative Authority to ADMinistrative Agencies}

I deal in this Part with the effects on the process of congressional and judicial control of administrative action of assigning adjudicatory responsibility over federal statutory schemes to courts of limited jurisdiction, staffed by specialized judges, subject only to review by the Supreme Court. These courts, falling within Types III and VI in the classification presented in the preceding Table, include the Federal Circuit, the Court of International Trade, the Court of Veterans Appeals, and the former Court of Customs and Patent Appeals. In Part V, I discuss how the arguments developed here apply to other types of courts.

Section A presents a model of control of agency action, and Section $\mathrm{B}$ discusses the differences, from the perspectives of this model, between generalist and specialized judges. I conclude that courts of limited jurisdiction, staffed by specialized judges, and subject only to review by the Supreme Court, decrease the effectiveness of congressional delegation of legislative authority to administrative agencies.

An important caveat is in order. I focus in this Part only on one very specific concern, and show why this concern counsels against the creation of specialized courts that are not subject to review by the generalist courts of appeals. There are, to be sure, competing arguments, ${ }^{128}$ and in Part V, I discuss the implications of these arguments for the design of specialized courts charged with the review of administrative action.

\section{A. A Model of Congressional and Judicial Control of Agency Action}

To address the effect of specialized courts on the process of delegation of congressional authority to administrative agencies, I present a model of legislative delegation that defines the problem of delegation to administrative agencies in traditional principal-agent terms. ${ }^{129}$ This discussion is the beginning of a larger project that

128 See supra notes $19-47$ and accompanying text.

129 Principal-agent analyses of the relationship between Congress and administrative agencies are influential in the political science literature. See, e.g., Fiorina, Legislator Uncertainty, Legislative Control, and the Delegation of Legislative Power, 2 J.L. Econ. \& ORg. 33 (1986); McCubbins, The Legislative Design of Regulatory Structure, 29 Am. J. Pol. Scr. 721 (1985); McCubbins, Noll \& Weingast, Administrative Procedures as Instruments of Political Control, 3 J.L. Econ. \& ORg. 243 (1987); McCubbins \& Page, A Theory of Congressional Delegation, in Congress: Structure and Policy 409 (M. McCubbins \& T. Sullivan eds. 1987); Weingast, The Congressional-Bureaucratic System: $A$ 
seeks to analyze, from a principal-agent perspective, the separation of powers doctrines defining the relationships among Congress, administrative agencies, and federal courts. ${ }^{130}$

In the model, Congress, the principal, delegates certain functions to its agent, the administrative agency, expecting that benefits will accrue to it through this delegation. ${ }^{131}$ For example, Congress might perceive that a social ill, such as homelessness, requires intervention by the federal government, and that the most effective attack on the problem is to create an administrative agency. At election time, if the agency has been loyal to Congress' wishes, members of Congress can claim credit for having enacted a statute that successfully addressed the problem.

As in all principal-agent problems, the interests of the principal and of the agent diverge; ${ }^{132}$ the effects of such divergence can be measured by what might be termed "divergence costs." Divergence costs are the difference betwreen the benefits that would accrue to the principal from the delegation if the agent were wholly loyal and the benefits that actually accrue to the principal given the agent's different interests.

In our political system, divergence between the interests of Congress and administrative agencies flows in part from the different cycles of elections for Congress on the one hand and for administrative agencies on the other. In Congress, the House of Representatives represents the political consensus of the last two-year election; in the Senate, one-third of the members represent that consensus, whereas the other two thirds represent the consensus of the prior two elections. As for administrative agencies, those within the Exec-

Principal Agent Perspective (with Applications to the SEC), 44 Puв. CHorce 147 (1984). They are virtually absent, however, from the legal literature.

130 See infra note 136.

131 For purposes of this analysis, I treat Congress as a single decisionmaker, rather than as a collection of individual legislators. Thus, I avoid the problems identified by Kenneth Arrow's famous theorem, which holds that, absent special conditions, it is not possible to construct a collective preference function from individual preference functions. See A. Sen, Collective Choice and Social WELFARE 41-46 (1970).

I make the same assumption with respect to administrative agencies. For agencies headed by a single individual, however, the assumption is less heroic.

132 See Holmstrom, Moral Hazard and Observability, 10 BELL J. ECoN. 74 (1979); Jensen \& Meckling, Theory of the Firm: Managerial Behaviour, Agency Costs and Ownership Structure, 3 J. Fin. Econ. 305, 308-10 (1976); Pratt \& Zeckhauser, Principals and Agents: An Overview, in Principals and Agents: The Structure of Business 1 (J. Pratt \& R. Zeckhauser eds. 1984); Ross, The Economic Theory of Agency: The Principal's Problem, 63 AM. Econ. REv. 134 (1973). 
utive Branch reflect the results of the last presidential election, whereas multi-member independent agencies generally reflect the results of several such elections, as heads of such agencies serve for staggered terms and cannot be removed by the President absent cause. Thus, even if the performance of the political parties in presidential and congressional elections were identical, an election that produced a President (and heads of executive agencies) of one party would not necessarily give that party control of the Senate, as only one-third of the Senate seats would have been at stake in that election.

A further cause of divergence is the increase in split ticket voting patterns. The number of congressional districts that have supported the presidential candidate of one party and the congressional candidate of another has risen from about 3 percent in 1900 to almost 44 percent in 1984. A recent study of congressional elections concluded:

Declining party loyalties, weakened coattail effects, and a lessened impact of national conditions on the congressional vote have produced numerous unrelated electoral mandates which members of Congress reasonably attribute more to their personal record than to the president's actions or the party's reputation. ${ }^{133}$

Congress can incur divergence costs even if the agency acts within the bound's of its delegated authority. The fact that Congress vests discretion in an agency does not mean that Congress is indifferent to how the agency exercises that discretion. ${ }^{134}$ It is difficult (and costly) for Congress to draft statutes that fully specify its intentions on every conceivable question that might interest it. As to questions that Congress has not addressed, a court will uphold any agency interpretation that is reasonable. ${ }^{135}$ Yet Congress may prefer certain interpretations over others.

One way Congress can reduce the level of these divergence

133 B. Cain, J. Ferejohn \& M. Fiorina, The Personal Vote: Constituency Service and Electoral Independence 17 (1987); see also Fiorina, An Era of Divided Government, in Developments in American Politics (B. Cain \& G. Peele eds.) (forthcoming 1990); Mashaw, Prodelegation: Why Administrators Should Make Political Decisions, 1 J.L. Econ. \& Org. 81, 95 (1985). For other studies of Congressional elections, see G. Jacobson, The Politics of Congressional Elections (1984); D. Mayhew, Congress: The Electoral Connection (1975).

134 The complications introduced by the possible divergence of interests between the current Congress and the Congress that enacted the legislation are discussed infra text accompanying notes 143-47.

135 See Chevron U.S.A., Inc. v. Natural Resources Defense Council, 467 U.S. 837,845 (1984). 
costs is by employing control tools and thereby incurring control costs. There are many such control tools at Congress' disposal. For example, Congress can overrule a particular regulation by amending the governing statute. However, because of inertial factors, this tool is used sparingly, and certainly is not invoked every time that Congress does not agree with an administrative decision. ${ }^{136}$

More importantly, Congress can control administrative action through the committee oversight process and the budget process, ${ }^{137}$ and through the Senate's role in consenting to the appointment of agency heads. ${ }^{138}$ These tools involve a relatively low commitment of congressional resources and therefore are used quite frequently. There is an extensive political science literature suggesting that these tools of control are effective. ${ }^{139}$

In addition to incurring control costs, Congress can amend the

136 Prior to INS v. Chadha, 4.62 U.S. 919 (1983), Congress also had legislative vetoes at its disposal under many statutory schemes. In a separate piece, I analyze Chadha as well as other separation of powers doctrines affecting administrative agencies, viewing the relationship between Congress and administrative agencies as one of principal and agent.

Chadha itself struck down a one-House legislative veto over decisions by the Attorney General to suspend the deportation of aliens. The Court's rationale in this case applies more broadly to any attempt by Congress to veto administrative action, including the promulgation of regulations, by a mechanism that does not comport with the Article I requirement of bicameralism (passage by both Houses) and presentment (to the President for his signature or veto). See id. at 944-59. For example, two months after the Supreme Court's decision in Chadha, the Supreme Court summarily affirmed a D.C. Circuit decision striking down a two-house veto of a regulation promulgated by the Fecleral Trade Commission. See United States v. FTC, 463 U.S. 1216 (1983). That veto provision satisfied the bicameralism requirement but not the presentment requirement. See id. at 1219 (White, J., dissenting).

137 See D. Arnold, Congress; and the Bureaucracy: A Theory of Influence 3-8, 214-15 (1979); R. Fenno, Jr., The Power of the Purse xiii-xxix (1966); J. Harris, Congressional Control of Administration 15-101 (1964); M. Kirst, Government Without Passing Laws: Congress' Nonstatutory Techniques for Appropriations Control 3-22 (1969); A. Wildavsky, The Politics of the Budgetary Process (4th ed. 1984).

For a discussion of the constirutional contours of the appropriations power, see Stith, Congress's Power of the Purse, 97 YALE L.J. 1343 (1988).

138 For evidence of Senate influence, see Senate Comm. on Commerce, Appointments to the Regulatory Agencies, S. Rep. No. 262-7, 94th Cong., 2d Sess. (1976).

139 See, e.g., Calvert, Moran \&: Weingast, Congressional Influence over Policy Making: The Case of the FTC, in Congress: Structure and Policy, supra note 129, at 493; Ferejohn \& Shipan, Congressional Influence on Administrative Agencies: A Case Study of Telecommunications Policy, in Congress Reconsidered 393 (L. Dodd \& $\mathrm{B}$. Oppenheimer 4th ed. 1989); McCubbins \& Schwartz, Congressional Oversight Overlooked: Police Patrols versus Fire Alarms, 28 Am. J. Pol. Scr. 165 (1984); Moe, Control and Feedback in Economic Regulation: The Case of the NLRB, 79 AM. Pol. SCI. Rev. 1094, 1101 (1985); Weingast, supra note 129, at 161-81; Weingast \& Moran, Bureaucratic 
substantive statute and instead of merely reversing a single decision, restrict the level of delegation. Indeed, if Congress disapproves of the agency's use of its discretion, it can prospectively reduce that discretion as a substitute for retrospectively setting aside a particular decision. However, like the overruling of a specific decision, this tool requires the full Article I legislative machinery.

Therefore, I shall assume that in the short-run, Congress is limited to expending control costs, such as through the oversight and budget process, or by overruling specific administrative decisions. It follows, then, that after a sudden change in the legal landscapesuch as the establishment of a specialized court to review administrative action previously reviewed in the generalist courts of appealsCongress will not change the level of delegation in the statute, because such a change would involve a fundamental restructuring of the statutory scheme. In the long-run, however, it can change the level of delegation as well.

For a given level of delegation to an administrative agency, I assume that a fixed quantum of benefits would accrue to Congress if the agency were wholly loyal. I also assume that divergence costs are a decreasing function of control costs, so that a greater expenditure in control costs leads to smaller divergence costs. Thus, Congress' objective function is to minimize the sum of control costs and divergence costs. In the short-run, Congress can affect the sum of these costs only by deciding how much to expend in control costs.

Congress' long-run problem is different in three important ways. First, whereas in the short-run it has only one decision variable (control costs), in the long-run it has two such variables (control costs and the level of delegation).

Second, Congress' objective function can no longer be expressed in terms of the minimization of the sum of control costs and divergence costs. When the level of delegation can vary, the benefits that would accrue to Congress if the agency were wholly loyal is no longer a constant. Congress' objective function is therefore to maximize the difference between the benefits and the sum of control costs and divergence costs. I assume that the level of benefits that would accrue to Congress if the agency were wholly loyal is an increasing function of the level of delegation because the agency faces fewer constraints in carrying out Congress' objectives. Thus,

Discretion or Congressional Control? Regulatory Policymaking by the Federal Trade Commission, 91 J. Pol. Econ. 765, 775-93 (1983). 
absent any divergence, greater delegation would produce greater benefits for Congress.

Third, divergence costs are no longer a function solely of control costs, as they were in the short-run, but also a function of the level of delegation. I assume that for a given expenditure in control costs, greater delegation results in greater divergence costs, as it becomes more difficult for Congress to monitor the agency's actions and to take appropriate corrective action. Divergence costs are thus an increasing function of the level of delegation.

So far, the description of the model has only dealt with the relationship between Congress and administrative agencies. The federal courts are also an important component of the administrative lawmaking system and play a valuable role in policing an agency's exercise of its delegated authority. Courts reinforce congressional control of administrative action in several ways.

First, by striking down certain administrative decisions, they can obviate the need for Congress to do so. ${ }^{140}$ However, as already indicated, the scope of judicial review of administrative action is more limited than that of congressional oversight, ${ }^{141}$ as Congress can attempt to influence an agency that has not strayed from its statutory bounds. ${ }^{142}$ The central question for judicial review is whether the agency stayed within the bounds of its delegated authority. Congress, in contrast, is not limited to this question, as it can also evaluate and attempt to influence: an agency that has not strayed from its statutory bounds. Nonetheless, over a certain range of agency decisions, the courts' control over administrative action reinforces Congress' own control.

Second, it is not even necessary for courts actually to strike down administrative decisions for their influence to be felt. The mere threat of this power can affect the operation of the administrative process. Even if there were no judicial decisions holding that an agency acted outside the scope of its authority, one should not conclude that judicial review does not complement Congress' efforts to

140 This function is particularly valuable if the reviewing court does not have systemic biases. See infra text accompanying notes 149-53.

141 See supra 135-39 and accompanying text.

142 I formulate this inquiry broadly to include the full scope of review contemplated by the Administrative Procedure Act, 5 U.S.C. $\S 706$ (1982), or by the judicial review provision of the applicable statute. For example, I assume that every delegation scheme imposes upon an agency the requirement of rationality. Thus, when an agency is found to have violated this requirement by acting in an "arbitrary and capricious" manner, it can be said to have strayed outside the bounds of its delegated authority. 
control administrative agencies. Indeed, in the absence of such review, Congress may have had to expend control costs itself, or to bear divergence costs.

Third, the courts perform a signaling function that is valuable to Congress. If Congress observes that an agency has a particularly poor litigating record in the federal courts, it may take corrective action in the form of a greater expenditure of control costs, or may decide, in the long-run, to reduce the level of delegation. In the absence of judicial review, it may be extremely costly for Congress to determine whether an agency routinely exceeds the bounds of its statutory authority.

I acknowledge that judicial review is not a perfect substitute for congressional control. For instance, in performing its review function, the judiciary is generally guided by the intent of the Congress that enacted a piece of legislation, as opposed to the current Congress. ${ }^{143}$ In contrast, it is the wishes of the current Congress that determine the expenditure of control costs. Undoubtedly, a more sophisticated model would take account of this effect.

I do not think, however, that this simplification detracts significantly from the validity of the analysis. As a result of the dominance of Congress by the Democratic Party in recent decades, ${ }^{144}$ the high reelection rates of members of Congress, ${ }^{145}$ and the long tenures of committee and subcommittee chairs ${ }^{146}$ (who have a disproportionate weight in the decision to expend control costs) there will be a rela-

143 There is strong academic support, however, for the proposition that the wishes of the current Congress matter as well. See, e.g., G. Calabresi, A Common LAW FOR THE AGE OF STATUTES 164 (1982) (stating that "the common law function to be exercised by courts . . . is no more and no less than the critical task of deciding when a retentionist or a revisionist bias is appropriately applied to an existing statutory or common law rule" (emphasis omitted)); R. DwORKIN, LAw's EMPIRE 348 (1986) (Hercules, the heroic judge, "rejects the assumption of a canonical moment at which a statute is born and has all and only the meaning it will ever have. Hercules interprets not just the statute's text but its life, the process that begins before it becomes law and extends far beyond that moment."); Aleinikoff, Updating Statutory Interpretation, 87 MrCH. L. REv. 20, 21 (1988) ("Congress builds a ship and charts its initial course, but the ship's ports-of-call, safe harbors and ultimate destination may be a product of the ship's captain, the weather, and other factors not identified at the time the ship sets sail. This model understands a statute as an on-going process (a voyage) in which both the shipbuilder and subsequent navigators play a role.").

144 See Fiorina, supra note 133.

145 The reelection rate in the House of Representatives for incumbents seeking reelection is approximately 98 percent. See Dodd \& Oppenheimer, Consolidating Power in the House: The Rise of a New Oligarchy, in CoNGRess ReCONSIDERED, supra note 139, at 39,41 .

146 See M. Kirst, supra note 137 , at 64. 
tive identity of interests across Congresses for a relatively long period of time. ${ }^{147}$

On the whole, the federal courts play an important role in aiding Congress' efforts to control administrative action. In Section B, I explain that specialized courts tend to perform this function less effectively than generalist courts because they are more likely to exhibit systemic biases, often in the agency's favor.

As a result, for a given level of delegation and for a given congressional expenditure in control costs, the divergence costs borne by Congress are higher for specialized courts than for generalist courts. The model yields several conclusions about the comparative effects of generalist and specialized courts. Proofs for the various propositions are provided in the Appendix.

In the short-run, in which the level of delegation is fixed, the creation of a specialized court to replace the generalist courts increases the sum of control costs and divergence costs. ${ }^{148}$ In addition, for plausible functional relationships linking control costs and divergence costs, Congress will expend more in control costs, but this expenditure will be less effective. ${ }^{149}$

In the long-run, in which the level of delegation can vary, specialized courts decrease the benefits that accrue to Congress from the delegation. ${ }^{150}$ Also, for plausible functional relationships, Congress will also expend more in control costs, and will delegate less than with generalist review of agency action. ${ }^{151}$ Thus, Congress is

147 For discussions of the roles of committees and subcommittees in the modern Congress, see, e.g., Hall, Committee Decisionmaking in the Postreform Congress, in Congress Reconsidered, supra nore 139, at 197; Rudder, Fiscal Responsibility, Fairmess, and the Revenue Committees, in id. at 225; Collie \& Cooper, Multiple Referral and the "New" Committee System in the House of Representatives, in id. at 245.

148 See Appendix, Proposition 1.

149 See Appendix, Proposition 2.

150 See Appendix, Proposition 3.

151 See Appendix, Proposition 4.

Opponents of excessive congressional delegation might view this latter result positively. But if the objective is to reduce the level of delegation, it makes far more sense to do so through the revival of the non-delegation doctrine, not successfully invoked since A.L.A. Schechter Poultry Corp. v. United States, 295 U.S. 495 (1935), and Panama Refining Co. v. Ryan, 293 U.S. 388 (1935), than by the establishment of specialized courts. Whereas the non-delegation doctrine can control the level of delegation directly, the impact of the establishment of specialized courts on this level will depend on the relationship between control costs and divergence costs. More fundamentally, opponents of the current broad levels of delegation must answer why it is undesirable for Congress to pick the level of delegation that maximizes its benefits. See infra text accompanying note 152 . 
unambiguously worse off when judicial review of agency action is performed by specialized courts.

A plausible objection to my analysis is that the benefits that Congress derives from delegation are not a proper criterion by which to evaluate social policy. One might postulate, for example, that there are principal-agent problems in the relationship between Congress and the People and therefore that the outcome that is desirable from the perspective of Congress is not necessarily a good one for the People. Such a view, which is held, for example, by adherents to the republican civic tradition, ${ }^{152}$ would require a far more complicated model of the process of delegation than I can attempt in this Article; or than has been undertaken in the literature. It is by no means clear, however, that such models would yield prescriptions different from mine. For the purpose of this Article, I equate benefits to Congress with benefits to the People.

\section{B. The Shortcoming of Specialized Judges as Instruments of Control of Administrative Action}

In Section A, I showed that if specialized courts are more likely than generalist courts to exhibit biases when they review agency action, they will have negative effects on the process of congressional delegation to administrative agencies. In this Section, I will argue that this result flows principally from the mechanisms of appointment of specialized judges. ${ }^{153}$

Formally, the appointment of Article III specialized judges is no different from that of Article III generalist judges. Under our constitutional scheme, all Article III judges are nominated by the President and are subject to Senate confirmation. ${ }^{154}$ Similarly, the Article I judges in the existing specialized courts are also appointed by the

152 For recent commentary on this tradition, see Michelman, Law's Republic, 97 YaLE L.J. 1493 (1988); Sunstein, Beyond the Republican Revival, 97 YaLE L.J. 1539 (1988).

153 Although commentators have raised arguments about the "capture" of specialized judges, they generally have not explored the mechanisms by which such capture can occur. See, e.g., Carrington, supra note 42, at 606-07 ("The usual method of appointing federal judges seems unsuitable because the hazards of political influence would be aggravated with respect to specialized appointments"); Jordan, supra note 13, at 748 ("[I]f judges are assigned to hear cases which are very important to organized interests, representatives of those interests may attempt to ensure appointment of favorably disposed judges or to persuade incumbents to adopt a favorable point of view.").

154 See U.S. Const. art. II, § 2; see also H. Chase, Federal Judges: The Appointing Process (1972) (discussing the appointment process and analyzing how different administrations have approached the process). 
President with the advice and consent of the Senate. ${ }^{155}$ The informal processes that provide the names of possible candidates for generalist and specialized courts, however, are likely to be quite different.

Even for United States district judges, presidential appointment does not mean that the President surveys the list of lawyers in a judicial district and selects the one that he prefers. In practice, it is often the senior Senator from the: President's party who selects nominees in his state, subject to a veto by the Justice Department. ${ }^{156}$ Many Senators, in turn, use screening committees, and those committees often elicit recommendations from various bar groups and other organizations. Also, nominees are formally evaluated by the American Bar Association (ABA), ${ }^{157}$ and perhaps by local bar associations. ${ }^{158}$ Because a negative rating can seriously endanger Senate confirmation, Senators are likely to select individuals capable of securing favorable ratings.

In the case of specialized judges, it is the bar groups concerned with a specialized court's jurisdiction that are likely to have an impact in recommending potential nominees and, later, in reviewing the actual nominee. For example, the Association of the Bar of the City of New York has decided to vest the initial responsibility for review of nominees to the Federal Circuit, the Court of International Trade, and the United States Tax Court in the committees with responsibility over the principal jurisdiction of those courts: Patents, International Trade, and Taxation respectively. ${ }^{159}$ In contrast, responsibility for the review of generalist federal judges is vested in the Committee on the Judiciary, ${ }^{160}$ which draws its members from a broader spectrum of the profession.

The important role that the nomination of specialized judges vests in bar committees that represent a narrow segment of the legal

155 See supra notes 95-96; supra text accompanying note 120.

156 See, e.g., H. Chase, supra note 154 at 10 ("As a corollary of the development of senatorial courtesy there grew a custom by which senators, when of the president's party, nominated to the president candidates for federal offices in their respective states and, if these candidates passed the president's muster, he appointed them."). This practice has longstanding vintage. See id. at 10-13.

157 The role of the ABA is reviewed in Public Citizen v. United States Dep't of Justice, 109 S. Ct. 2558, 2560-61 (1989).

158 For example, the Association of the Bar of the City of New York reviews all district court nominees in the Southern and Eastern Districts of New York. See Association Review of Indiziduals Being Considered for Positions of Public Trust: An Executive Committee Position, 42 Rec. A.B. CrTY N.Y. 787, 789 (1987).

159 See id. at 789.

160 See id. at $787,789$. 
profession makes that process a possible target for capture by special interest groups. If a group of this type could gain control over a bar committee by placing a substantial number of individuals on the committee who share its viewpoint, it would obtain an important voice over the nomination process for specialized judges. ${ }^{\mathbf{1 6 1}}$

Because the committees relevant to the appointment of generalist judges have a broader membership, capture is less likely to occur for a number of reasons. First, the costs of capturing a broader committee are higher. For example, a trade association attempting to relax environmental standards might place several sympathetic individuals in the relevant specialized committee. But such a group could not achieve the same result with a committee that has representatives of the broader legal profession. In such a committee there would probably be no more than one practitioner of environmental law, and it will generally be difficult for the interest group to ascertain the views on environmental law of practitioners in other areas.

Moreover, from the perspective of a cohesive group, the benefit that accrues from the capture of the appointment process may be greater for specialized courts than for generalist circuit courts. The former are generally organized as single courts, ${ }^{162}$ and are the final authority aside from the Supreme Court. The latter, in contrast, are only one voice in a process of dialogue with co-equal courts. Thus, capture by a single group of the nomination process for a specialized court is more likely than that for a generalized court because in addition to being less costly, it has the potential to yield greater benefits. ${ }^{163}$

161 Commenting on the proposed Environmental Court, see supra note 12, the Conservation Foundation, an environmental public interest group, noted:

To set up an environmental judiciary in splendid isolation from their brethren on the bench is also to set them up as vulnerable targets for pressures and criticisms from all sides. Because they will be handling only one type of case, efforts will be made from the outset-by those at all points on the environmental spectrum-to ensure that the judges chosen are of the proper "environmental persuasion." Thus, the appointment process itself will hold greater political interest than in the case of the ordinary district court judge who will decide cases on every conceivable subject.

Report of the President, supra note 33, at VI-6.

162 See supra text accompanying note $\mathbf{5 6}$ (discussing an early congressional proposal to organize a specialized court into circuits).

163 One commentator has noted that:

[Generalist] [j]udges . . . will spend only a tiny fraction of their time and energy dealing with environmental disputes. For this reason the process of judicial selection is not significantly affected by anyone's estimate of a given judge's attitudes about those issues. This is a most important fact, 
While one could hypothesize a situation where different interest groups would combine to capture the process of nomination of generalist judges, it is unlikely, given the wide range of issues within the jurisdiction of the generalist federal courts, that a coalition would form behind a single candidate. Even if such a candidate could be found, there would be serious free-rider problems. Any single group would have an incentive to withdraw from the coalition and have the other groups bear the costs of capture. ${ }^{164}$

Congress recognized the greater likelihood of capture of a court charged with the review of a single agency when it established the Federal Circuit. As indicated above, Congress vested the Federal Circuit with jurisdiction in several distinct areas, and expanded this jurisdiction beyond the cornbined jurisdictions of its predecessors, the Court of Claims and the Court of Customs and Patent Appeals. Explaining this decision, the report accompanying the Senate bill noted:

This rich docket assures that the work of the proposed court will be broad and diverse and not narrowly specialized. The judges will have no lack of exposure to a broad variety of legal problems. Moreover, the subject matter of the new court will be sufficiently mixed to prevent any special interest from dominating it. ${ }^{165}$

Even for specialized courts that review a single agency, where the danger of capture is the greatest, the extent to which any nomination process, and, consequently, any specialized court, may exhibit biases depends upon the organization of the specialized bar and on the manner in which the interests of its clients are structured. ${ }^{166}$

one which can hardly be applied to any institution that deals regularly with environmental matters. A President or a Governor who is choosing an environmental council cannot avoid consideration of the attitude that important interest groups--whether the oil industry or conservation organizations-will adopt toward that choice.

J. Sax, Defending the Environmient: A Strategy for Citizen Action 109 (1971). 164 See M. Olson, The Logic of Collective Action (1971). In this respect, the nomination to the Supreme Court of Judge Robert Bork is an anomaly, in that groups concerned with a wide variety of different issues were able to successfully combine their efforts. But I do not think that free-rider problems are likely to be solved as effectively for the lower courts. For an illuminating analysis of the Bork nomination, see E. BronNer, Battle for Justice: How the Bork Nomination SHOOK AMERICA (1989).

165 S. ReP. No. 275, supra note 2, at 6, reprinted in 1982 U.S. Code Cong. \& ADMin. News at 16.

166 Several distinct categories are relevant to this inquiry. First, the specialized bar could be unified, so that attorneys regularly appear on both sides of a particular issue, and their clients do not corisistently favor one resolution of a particular issue over another. Patent law is an example of this model. Professor Dreyfuss notes: 
From the perspective of the principal-agent model analyzed in Section $A$, it is irrelevant whether the bias of specialized judges that results from the capture of the nomination process favors or disfavors the agency. From Congress' perspective either result is undesirable. If the bias of specialized judges favors the agency, judicial review will fail to set aside agency decisions that are, from the perspective of an unbiased adjudicator, outside of the domain of delegated discretion. Thus, for a given expenditure of control costs, Congress will bear additional divergence costs.

If, on the other hand, the bias of specialized judges disfavors the agency, judicial review will result in courts setting aside agency decisions that are consistent with the will of Congress. Here, it is the judicial review itself that increases the divergence costs that Congress must bear.

While the direction of the bias is not important to my argument, it is worth noting that at least for some statutory schemes the bias is likely to favor the agency. There may be similarity in the process of nomination of an agency head and of a specialized judge charged with reviewing an agency head's decisions. A group interested in securing the nomination of a specialized judge with a particular outlook would also be interested in an agency head with the same outlook. The group would have to deal with a different informal process, particularly since the bar associations have traditionally confined their concern to judges, but that process might be susceptible to the same type of capture.

Furthermore, at least for agencies within the Executive Branch, the Justice Department will have a strong interest in securing the nomination of individuals likely to be sympathetic to the agency that they would review. Not only would such an outcome serve to promote the interests of the Executive Branch but it would also enhance

[L]itigants with the greatest power probably are vertically integrated companies. These firms cannot usually forecast which side of a patent issue will favor their interests, as they encompass not only research arms that develop patented innovations, but also manufacturing arms that operate under licenses for inventions patented by others.

Dreyfuss, supra note 13 , at 29.

A second category is one in which the bar is not unified, in that lawyers typically appear on only one side of a particular issue, but in which there is a strong group on each side of the issue. Third, there could be a disparity of power and influence between the two distinct groups. Environmental law may fall in this category, in that the bar representing regulated industries is likely to be far more numerous and powerful than the bar representing environmentalist groups. Of course, the dangers of capture are more salient in the third category than in the first or second. 
the Justice Department's own effectiveness as the lawyer for agencies within that branch.

It is true that even in the case of generalist judges, the Justice Department has an interest in the nomination of individuals sympathetic to the Executive Branch's interests. But the generalist courts deal with a wide range of issues that intimately interest the Executive Branch. Therefore, the Justice Department is forced to perform tradeoffs that result in less identity between the views of the nominee on an agency-specific issue and the views of the relevant agency. ${ }^{167}$

For example, under a scheme of specialized courts, the Justice Department can strive for a perfect identity between the views of a nominee to a hypothetical Court of Social Security Appeals and those of the Social Security Administration. If, in contrast, the responsibility for judicial review of this agency's decisions remains in the generalist courts, the Justice Department would have to consider whether a nominee that is desirable from the perspective of the Social Security Administration is also desirable from the standpoint of, say, the Department's own interest in the enforcement of federal criminal law. It is unlikely that any individual would be ideal from all perspectives.

Of course, the influence of the Justice Department is likely to be the strongest, and the biasing effect most pronounced, where the Department faces a weak private bar, as is true, for example, in Social Security cases. There, the bar is unlikely to provide strong counterweight to the Department's interest in securing sympathetic judges on the specialized court. In contrast, where the Department faces a strong private bar, the effect will be considerably mitigated, and may in fact pull in the opposite direction as a result of the group's capture of the nomination process.

The concern about the Government's influence over specialized courts is borne out by the experience of the Tax Court. As a result of fears of bias, Congress repeatedly considered prohibitions against service on the Tax Court (and on its predecessor courts) ${ }^{168}$ of former Government officials. ${ }^{159}$ In fact, the Senate version of the Reve-

167 See R. Posner, supra note 13 , at 154 ("It is easier to predict how someone will decide cases in his specialty than how he will decide cases across the board; therefore, if courts are specialized, the officials who appoint judges will be better able to use the appointments process to shape the court ....").

168 See supra note 9.

169 In a comprehensive history of the court, Harold Dubroff noted:

When the first appointments to the Board [of Tax Appeals] were announced in the summer of 1924, a wave of protest issued from 
nue Bill of 1926 included a provision prohibiting service on the Board of any person who had been employed by the Bureau of Internal Revenue within two years of his appointment to the Board; the provision was deleted in Conference. ${ }^{170}$ Despite further efforts by Congress, several members have come to the Tax Court from recent service in the Treasury Department. ${ }^{171}$

In summary, compared to generalist judges, specialized judges are likely to be more biased arbiters of whether an agency has strayed beyond the bounds of its delegated authority. I do not thereby suggest that generalist judges have no biases; ${ }^{172}$ my limited claim is that specialized judges are likely to exhibit structural biases, and therefore that they are likely to decrease the effectiveness of congressional delegation to administrative agencies. ${ }^{173}$

accountants and, to a lesser extent, lawyers. They felt that the purpose of Congress in removing the Board from the Treasury Department and making it an independent executive agency would be thwarted if Treasury played a part in selecting appointees for the Board. Even more damaging would be a Board dominated by former employees of the tax collection system, supposedly imbued with a pro-Government bias, and of the first 12 appointees, five came directly from employment with Treasury or the Solicitor, three had been so employed previously, and two had been officials of state taxing agencies.

H. DuBRofF, supra note 9 , at 147.

170 See 67 Cong. Rec. 3754 (1926); see also H. Dubroff, supra note 9, at 147.

171 See $H$. Dusroff, supra note 9 , at 150 .

172 For a model of judges as faithful, unbiased enforcers of the congressional will, but of agencies as biased enforcers of that will, see Fiorina, supra note 129, at 39. 48.

173 An additional potential source of bias is that Article I specialized judges serve for limited terms. See supra notes 95-96; see also text accompanying note 120. Article III specialized judges may be more likely to leave the bench than their generalist counterparts because of the lower prestige of their jobs, see infra note 174 and accompanying text. Thus, they may be biased during their tenure because of concerns about post-judicial positions.

In particular, specialized judges may seek high-level appointments within the agency that they review. Such switches confer upon them supervision over the agency's non-adjudicatory functions and managerial responsibility for a large bureaucracy. Moreover, because the private sector values knowledge of the informal administrative processes more highly than the more formal judicial processes, a stint within the agency may give a specialized judge a good launching pad into a lucrative practice.

However, I have surveyed the career patterns of specialized judges, see $\mathrm{H}$. Dubroff, supra note 9 (Tax Court); G. Rich, A BRIEF History of the UnIted States Court of Customs and Patent Appeals (1980) (Court of Customs and Patent Appeals), and it does not appear that large numbers of judges on specialized courts have left the bench. In the Tax Court, for example, where judges have fifteen-year terms, reappointments have been practically routine. See supra note 95; H. DuBrofF, supra note 9 , at 212,215 . In fact, during the early 1950 s, because of a subsequently remedied lack of proper pension coverage, judges "were compelled to remain on the 


\section{Specialized Courts and the Judicial System}

There are structural reasons to expect that specialized courts not subject to review in the generalist courts of appeals are likely to decrease the quality of the output of the judicial system. In Section A, I will focus on courts of exclusive, though not necessarily limited, jurisdiction. Included in this group are courts labeled as Types I, IV, and VI in Table III. They include the D.C. Circuit, the Federal Circuit, the Temporary Emergency Court of Appeals, the Court of International Trade, the Court of Veterans Appeals, the former Commerce Court, the Emergency Court of Appeals, and the Temporary Emergency Court of $A$ sppeals.

In Section B, I will analyze the effects of courts of limited, though not necessarily exclusive, jurisdiction, staffed by specialized judges. Included in this group are courts labeled as Types III and VI in Table III-the Federal Circuit, the Court of International Trade, the Court of Veterans Appeals and the former Court of Customs and Patent Appeals.

The negative effects discussed in this Part are independent of the relative abilities of specialized and generalist judges. If the system of judicial review would suffer even if the specialized courts were able to attract the same caliber of personnel as generalist courts, it follows, a fortiori, that it would suffer even more if, as is likely, the caliber of specialized judges were lower. ${ }^{174}$

court for financial reasons when age and health considerations might otherwise have led them into retirement." Id. at 203. This evidence, however, does not exclude the possibility that in the case of specialized courts in other areas, the future career paths of specialized judges will be a source of systemic bias.

174 See, e.g., R. POSNER, supra note 13, at 150-51; Remarks of Justice Antonin Scalia, supra note 44 , at 10.

Specialized judges were not always perceived as having lesser status. For example, describing the Commerce Court, Felix Frankfurter and James Landis stated: "Probably no court has ever been called upon to adjudicate so large a volume of litigation of as far-reaching import in so brief a time." F. FRANKFURTER \& J. LANDIS, supra note 61, at 164 .

Around the turn of the century, Congress set the salaries of specialized judges at a level higher than those of generalist judges. For example, the Tariff Act of 1909 , ch. $6, \S 29,36$ Stat. 11, 105, provided that judges on the Court of Customs Appeals would have a salary of $\$ 10,000$, which was $\$ 3000$ higher than the salary of judges on the generalist courts of appeals. This differential generated controversy, however, and Congress equalized the salaries before any judges had taken office. See G. RICH, supra note 173 , at $7-8$.

There is at least one piece of evidence suggesting that the higher salaries would have added to the status of the specialized courts. President Taft's original nominee for presiding judge of the Court of Customs Appeals was Judge Alfred Coxe, a sitting judge on the U.S. Circuit Court of Appeals. Following the equalization of the salaries 
Here too, I must make the important caveat that this Part seeks to analyze a set of arguments that generally counsel against the creation of specialized courts that are not subject to review in the generalist courts of appeals. Firm conclusions about the relative desirability of specialized courts, or a comparison of the desirability of various types of specialized courts, must await Part V.

\section{A. Multi-Circuit Consideration of Legal Issues}

An important, and seemingly puzzling, characteristic of the federal legal system is the absence of intercircuit stare decisis among the regional courts of appeals. ${ }^{175}$ It is now well established that "the federal courts spread across the country owe respect to each others' efforts and should strive to avoid conflicts, but each has an obligation to engage independently in reasoned analysis." 176 At first glance, the absence of intercircuit stare decisis appears incongruous in the context of judicial review of administrative action. After all, one of the central New Deal justifications for the creation of administrative agencies was their role in promoting the uniformity of federal law. ${ }^{177}$ Why, then, should we take uniform administrative decisions and subject them to review in the various regional circuit courts under a system that makes it possible for these courts to disagree with one another, thereby creating at least temporary disuniformity?

If disagreement among the circuits played no useful role, the case for a specialized court not subject to review in the generalist courts of appeals jurisdiction would be an easy one. ${ }^{178}$ Such courts would guarantee immediate uniformity of federal law-a generally undisputed goal-at no cost. But the reality is quite different

of judges, Judge Coxe indicated that he was no longer interested in serving on the new court. See id. at 8.

175 See supra text accompanying note 15.

176 In re Korean Air Lines Disaster of September 1, 1983, 829 F.2d 1171, 1176 (D.C. Cir. 1987), aff'd sub nom. Chan v. Korean Air Lines, 109 S. Ct. 1676 (1989); see also Colby v. J.C Penney Co., 811 F.2d 1119, 1123 (7th Cir. 1987) (Posner, J.) ("Bearing in mind the interest in maintaining a reasonable uniformity of federal law and in sparing the Supreme Court the burden of taking cases merely to resolve conflicts between circuits, we give most respectful consideration to the decisions of the other courts of appeals and follow them whenever we can."); Aldens, Inc. v. Miller, 610 F.2d 538, 541 (8th Cir. 1979) ("As an appellate court, we strive to maintain uniformity in the law among the circuits, wherever reasoned analysis will allow, thus avoiding unnecessary burdens on the Supreme Court docket."), cert. denied, 446 U.S. 919 (1980).

177 See J. LANDIs, supra note 14 , at $30,33$.

178 So too, of course, would be the case for intercircuit stare decisis. 
because of the benefits that attach to a system in which there is no intercircuit stare decisis.

First, allowing one circuit to disagree with another creates an effective mechanism for rationing a judge's time so that difficult cases receive increased attention. Suppose that a judge devotes to each case a certain amount of time, and on that basis reaches a tentative decision. The judge then asks herself whether there is some reason why the case merits additional scrutiny, and either makes final her tentative decision or considers the issue further.

A central ground rule of our system of regional courts of appeals is that the opportunity to disagree with another circuit is accompanied by the obligation to take seriously that circuit's views, thereby avoiding unnecessary conflicts. ${ }^{179}$ It follows that judges should pay additional attention to tentative decisions that are inconsistent with the rulings of other circuits.

Quite aside from this requirement, judges are likely to be inclined to give further scrutiny to such cases. The contrary decision of another circuit should lead judges to doubt their tentative assessments. Moreover, cases that produce a conflict among the circuits generally receive extensive scrutiny in the legal community, and judges are likely to want their decisions to stand up well to such scrutiny.

Cases in which a judge's tentative decision differs from the decision of another circuit are likely to be hard cases. ${ }^{180}$ Thus, the possibility of intercircuit disagreement provides a simple device for signaling that certain hard cases are worthy of additional judicial resources. While it may well be that sometimes the tentative decision will have been the better one, in the aggregate the quality of adjudications is likely to be positively correlated with the effort expended. In a judicial system in which heavy dockets place constraints on the amount of time that a judge can devote to a single case, it is quite beneficial to have mechanisms for identifying categories of cases in which an additional expenditure of resources is likely to lead to better decisions.

Second, the doctrinal dialogue that occurs when a court of appeals addresses the legal reasoning of another and reaches a contrary conclusion also improves the quality of legal decisions. A logi-

179 For an extensive review of the authorities, see Estreicher \& Revesz, The Uneasy Case Against Intracircuit Nonacquiescence: A Reply, 99 YALE L.J. 831,834 \& n.18 (1990).

180 See $\mathrm{R}$. POSNER, supra note 13 , at 163. 
cal corollary to the requirement of avoiding unnecessary conflicts is the obligation of explaining the basis of disagreement when a decision is in conflict with another circuit. The circuit to have ruled first may well find such an explanation persuasive and reconsider its position. Alternatively, it may find the explanation unpersuasive, and set forth in a subsequent case the reasons for its disagreement. Circuits that have not yet ruled will then have a sharp account of the reasons for the different approaches and be in a better position to tackle the issue than they would be without such guidance.

Third, as a result of the absence of intercircuit stare decisis, the courts of appeals can also benefit from experiential dialogue by observing the consequences of different legal rules on the parties affected by such rules. For example, suppose that one circuit adopts rule $A$ and some time later another circuit adopts rule $B$. After the passage of some time, the courts may be able to observe and compare the actual effects of these two rules. Such evidence will be relevant both to circuits that have not yet considered the issue as well as to ones that may wish to reconsider their position. The courts of appeals can thus serve as laboratories that generate empirical data as to the effects of legal rules.

Intercircuit dialogue not only benefits the quality of adjudication by the courts of appeals, but also aids the Supreme Court's adjudication of cases involving conflicts among the circuits. The Court benefits both in its consideration of the legal merits of an issue and in its case selection decisions. ${ }^{181}$

On the first front, doctrinal dialogue isolates the issues on which the courts of appeals are divided, and presents the competing positions on those issues, probably stated in their strongest form. Thus, the identification, through intercircuit conflicts, of issues likely to be difficult allows the Court to deploy its resources more effectively. And, once it focuses on those issues, it is helpful for the Court to have the competing positions articulated from the relatively unbiased perspective of the courts of appeals, rather than from the necessarily biased perspective of the litigants.

In terms of experiential dialogue, the Supreme Court's decisions, like those of the circuits, are aided by the existence of an empirical data base. The value to the Court of such information is

181 The contours and effects of the rules governing the Supreme Court's selection of cases for review is explored in Revesz \& Karlan, Nonmajority Rules and the Supreme Court, 136 U. PA. L. REv, 1067 (1988). 
illustrated by the treatment of McCray $v$. New York. ${ }^{182}$ There, two Justices voted to grant certiorari to decide whether the Constitution prohibits the use of peremptory challenges to remove blacks from juries because of race. ${ }^{183}$ Three other Justices, who apparently believed that this question was worthy of review, noted, however, that "further consideration of the substantive and procedural ramifications by other courts w[ould] enable [the Court] to deal with the issue more wisely at a later date." 184 They added: "[I]t is a sound exercise of discretion for the Court to allow the various states to serve as laboratories in which the issue receives further study before it is addressed by this Court." 185

Perhaps even more importantly, the conflicts produced by intercircuit dialogue play a useful function in signaling to the Court the difficulty of particular issues, and thereby helping the Court make better case selection decisions. It might seem odd that the loss of this signaling device should be considered a cost of a specialized court of exclusive jurisdiction. After all, if review of particular agency determination were vested in such a court, rather than in the regional circuits, there would not be conflicts. One might argue, therefore, that a specialized court would eliminate the need for Supreme Court intervention altogether.

Undoubtedly there are some issues that divide the courts of appeals in which all that matters is that a uniform rule be fashioned. These are trivial conflicts of the "whether to drive on the right or drive on the left" type. It makes little difference which side of the road we drive on as long as we all drive on the same side. These conflicts are trivial not because I doubt that their resolution can sometimes be important but because a coin toss could eliminate them as effectively as the Supreme Court. ${ }^{186}$

For many issues that produce conflicts among the courts of appeals, however, outcome does matter. If cases that would have

182461 U.S. 961 (1983).

183 See id. at 963 (Marshall, J., joined by Brennan, J., dissenting from denial of certiorari).

184 Id. at 962 (Stevens, J., jcined by Blackmun and Powell, JJ., respecting the denial of certiorari).

185 Id. at 963 (Stevens, J., jcined by Blackmun and Powell, JJ., respecting the denial of certiorari). Three years later, in the face of a conflict among the circuits, the Court decided the issue. See Batson v. Kentucky, 476 U.S. 79 (1986).

186 The cases themselves need not be unimportant. For example, Judge Friendly has stated that " $[t]$ he incerpretation of tax statutes is typically the kind of issue where 'it is more important that the applicable rule of law be settled than that it be settled right; indeed, the Government's interest often is only that it not be whipsawed." H. FRIENDLY, supra note 13, at 167. 
generated a conflict among the courts of appeals are decided instead in a specialized court, there is a greater probability that the court's decision will be wrong. As Judge Posner has noted:

An issue that provokes a conflict among the circuits that is not immediately eliminated by one circuit's receding from its previous position is likely to involve a difficult question; and a difficult legal question is more likely to be answered correctly if it is allowed to engage the attention of different sets of judges deciding factually different cases than if it is answered finally by the first panel to consider it. ${ }^{187}$

It is extremely difficult for the Supreme Court to identify, from among all the issues decided by a specialized court of exclusive jurisdiction, those that would have generated a conflict if they had been decided instead by the regional courts of appeals, or those in which the process of dialogue would ultimately have produced a uniform contrary decision in the regional courts of appeals.

Thus, for cases that the Supreme Court identifies as worthy of review, the costs of making this identification are greater when the decision below is rendered by a specialized court of exclusive jurisdiction, rather than by the regional courts of appeals. And for decisions of specialized courts that the Supreme Court fails to identify, there will be a greater likelihood of an erroneous decision, as a diffcult issue will have received the scrutiny of only one court. ${ }^{188}$

Courts of exclusive jurisdiction therefore present a tradeoff. On the one hand, they eliminate the need for the Supreme Court to decide conflicts in cases in which the outcome is trivial but uniformity is important. On the other, the Supreme Court would have difficulty in identifying important cases that have been erroneously decided. ${ }^{189}$

The tradeoff can be analyzed more precisely by reference to a

187 R. POSNer, supra note 13 , at 163.

188 The converse problem is also present. If many generalist courts adopt a consistent approach to a particular issue, there should be a strong presumption that the issue was correctly decided and that Supreme Court review is not necessary. In contrast, it is more difficult for the Supreme Court to ascertain that an issue was decided correctly by a specialized court. If, with respect to a particular issue, the Supreme Court believed that a correct disposition was important, the lack of a signaling device might result in an unnecessary grant of certiorari. Thus, specialized courts of exclusive jurisdiction introduce both Type I and Type II errors-they lead the Court both to grant certiorari in cases that it should deny, and to deny certiorari in cases that it should grant.

189 If there were subject matters for which only uniformity was important, the negative effects of specialized courts would not be present. This question is explored further in Part V. 
two-by-two matrix. The variables on the two axes are uniformity and outcome. For a particular case, each variable can be either important or unimportant. This model defines four relevant types of cases. While actual cases certainly lie along the two continuums, this simplification aids the discussion of the effects of specialized courts of exclusive jurisdiction. ${ }^{190}$

Table IV: Tradeoff Between Specialized and Generalist Courts

\begin{tabular}{l|c|c|c}
\multicolumn{2}{c}{} & \multicolumn{2}{c}{ Uniformity } \\
\cline { 3 - 4 } & & Unimportant & Important \\
\hline \multirow{2}{*}{ Outcome } & Unimportant & Class A & Class B \\
\cline { 2 - 4 } & Important & Class C & Class D \\
\hline
\end{tabular}

For cases in Class A, where uniformity and outcome are both unimportant, the Supreme Court should not grant certiorari even if there is a conflict. For these cases, it does not matter whether the review of agency action occurs in specialized or generalist courts.

In Class $\mathrm{B}$, the trivial conflicts in which uniformity is important, specialized courts of exclusive jurisdiction are preferable because they articulate a uniform rule more cheaply than the current system of generalist regional courts, where uniformity might be achieved only after extensive dialogue and possible intervention by the Supreme Court.

In Class $\mathrm{G}$, for which outcome is important but uniformity is unimportant, generalist courts yield better results. Even if a conflict remains unresolved, the system is better off under the higher quality of adjudication that flows from intercircuit dialogue.

Finally, in Class D, for which both uniformity and outcome are important, in the absence of Supreme Court review, specialized courts of exclusive jurisdiction will better produce uniform results at

190 Class $\mathrm{C}$ is defined by cases for which it is preferable to have a desirable rule in some places and an undesirable rule in others, rather than an undesirable rule everywhere. 
the cost of lower quality. If the Supreme Court has sufficient decisional capacity to grant certiorari in all cases in Class D, the generalist approach is more desirable, as it becomes comparable in terms of uniformity-albeit uniformity at a somewhat higher cost-and remains better in terms of outcome.

The most recent and comprehensive study of the Supreme Court's exercise of its certiorari jurisdiction concluded unambiguously that the small number of conflicts denied review "undermine[s] the claim that docket incapacity prevents the Court from resolving conflicts among the circuits,"191 particularly where the conflicts affect the operation of federal administrative agencies. ${ }^{192}$

Therefore, the benefits that specialized courts of exclusive jurisdiction generate with respect to uniformity for cases in Class B must be weighed against their costs with respect to outcome for cases in Classes $\mathrm{C}$ and $\mathrm{D}$. The latter are the truly important cases in our legal system, and absent a more compelling account of the Supreme Court's docket pressure than has yet been presented, we should not compromise the adjudication of those cases in order to obtain uniformity more cheaply in cases that are not important. ${ }^{193}$

\section{B. Coherence of Federal Law}

Specialized courts not subject to review in the generalist courts of appeals can also interfere with the development of a coherent body of law and thereby decrease the quality of adjudication. Whereas the prior section focused on specialized courts of exclusive jurisdiction, here I analyze the effects of courts of limited jurisdiction staffed by specialized judges, and principally of specialized courts responsible for the review of a single agency, subject only to review by the Supreme Court.

I deal here only with external coherence-the coherence of federal law as a whole. In Part V, I discuss the benefits of specialized courts of a single statutory scheme-and offer some suggestions on the optimal mix of external coherence and internal coherence.

When a generalist judge decides a particular question, she looks for analogies not only in the specific area of law in which the question arises, but also in other areas within her subject matter jurisdic-

191 S. Estreicher \& J. SeXton, supra note 15, at 103.

192 See Estreicher \& Revesz, supra note 179, at 834-36.

193 The question whether there may be areas that, across the board, are not important, is explored in Part V. 
tion. Each of these areas provide reference points that are used in the process of adjudication.

For example, notions of improper intent pervade many areas of law. Such notions arise, for example, in tort law, criminal law, discrimination law, and antitrust law. I will assume that in deciding a novel question concerning intent in tort law, a judge performs the following steps. First, she reaches a tentative decision on the proper legal principle, based only on her consideration of tort law. Then, she identifies the relevant reference points, which consist of decisions involving similar questions about intent in other areas of law. Next, she tests her tentative decision against each of these reference points. If the judge finds no tension between her tentative decision and these reference points, the tentative decision becomes final. In contrast, if the judge identifies such tension, she reformulates the legal principle and tests this new formulation against the reference points. This process continues until no tension remains between the principle articulated to govern the tort case and each of the reference points.

For example, consider a tentative decision of the form: "Intent means $A . "$ The judge then checks against the reference points and finds the following principle in a case involving criminal law: "Intent means $B$." To harmonize this discrepancy, she reformulates her tentative decision: "Intent means $A$ except where there is a deployment of governmental power."

Once again, the judge tests her principle against the reference points and observes that in cases involving discriminatory acts by state officials, "intent means. $A$." But such cases involve the deployment of governmental power, so there is tension between the reformulated principle and this reference point. Thus, the judge attempts to refine the principle further. ${ }^{194}$

This testing and re-testing of legal principles in varied factual contexts, a practice that can be described as the search for coherence, undoubtedly improves the quality of decisionmaking. ${ }^{195}$ First,

194 The process is somewhat akin to that of solving simultaneous equations. Many solutions will satisfy a single equation, but most of those solutions will not satisfy the other equations. Similarly, many principles will satisfy one area if it is considered in isolation, but the set of principles that satisfies all the relevant reference points will be much smaller.

195 As Judge Posner notes:

Judicial specialization would . . . reduce the cross-pollination of legal ideas. Those who think that the basic concepts of antitrust law are totally different from those of tort law will not be troubled by this. But those who think, like Holmes, that there is a general legal culture that enables 
it expands the landscape from which the judge draws insights. But perhaps more importantly, it forces her to think more precisely about which of the many features of a case are legally relevant. The resulting principles will be better tailored to the specific problem that they will govern, as they are less likely to be either overinclusive or underinclusive. ${ }^{196}$ They will be, in short, principles of higher quality.

Of course, not every generalist judge employs this system of decisionmaking in every case, nor do I think that it would necessarily be desirable for a such a judge always to look beyond the specific area in which she is adjudicating. Instead, I make the far more modest claim that it is desirable for a court to have the capacity to perform such an inquiry at least occasionally, when a difficult, unsettled legal question merits this extraordinary expenditure of resources. ${ }^{197}$

Specialized judges who deal with only one area of law are simply not equipped to discharge this role effectively. Indeed, as discussed in Part III, specialized judges tend to come from relatively narrow segments of the profession and are therefore less likely than general-

those broadly immersed in it to enrich one field with insights from another will see this as still another drawback of specialization.

R. POSNER, supra note 13, at 156-57 (citing Letter from Oliver W. Holmes to John C. H. We (May 14, 1923), reprinted in Justice Oliver Wendell Holmes: His Book Notices and Uncollected Letters and Papers 163-64 (H. Shriver ed. 1936)).

Ronald Dworkin argues that coherence should be valued for its own sake. See R. DwORKIN, supra note 143, at 166-67. Coherence, he argues derives from the virtue of political integrity, which he divides inte two principles:

The first is the principle of integrity in legislation, which asks those who create law by legislation to keep that law coherent in principle. The second is the principle of integrity in adjudication: it asks those responsible for deciding what the law is to see and enforce it as coherent in that way. Id. at 167. He adds that "[t]he adjudicative principle of integrity instructs judges to identify legal rights and duties, so far as possible, on the assumption that they were all created by a single author-the community personified-expressing a coherent conception of justice and fairness."

Id. at 225.

In Dworkin's world, Hercules, "an imaginary judge of superhuman intellectual power and patience who accepts law as integrity," $i d$. at 239 , and tests each plausible interpretation by asking whether a single person could have given the verdicts in the previous cases if that official had tried to coherently enforce the principles that form the interpretation. See id. at 242-45.

In my discussion, the search for coherence has the principal goal of forcing judges to think more deeply about the cases before them. In Dworkin's world, it ensures that the state acts in principled ways. See id. at 243 . Another possible virtue of coherence has an economic basis: it ensures that law not work at cross purposes.

196 In the preceding example, the first tentative decision was overinclusive, but the process described also applies to underinclusive principles.

197 See R. Dworkin, supra note 143, at 264-66. 
ist judges to have been exposed to a wide range of legal issues. Moreover, because they do not adjudicate cases outside their area of specialization, they are also unlikely to broaden their outlook once on the bench. Thus, in general, specialized judges will be less skilled than their generalist counterparts at applying concepts from other areas of law, even if the relevant reference points were brought to their attention.

This problem may well be exacerbated by the bar that can be expected to form around a specialized court. Experience with specialized courts suggests that such courts will develop idiosyncratic procedures. ${ }^{198}$ When a court's procedures are not common to those of other courts, the high cost of becoming familiar with such procedures provides serious disincentives for lawyers to practice before the specialized court only occasionally. Thus, lawyers who practice before specialized courts will be less likely than those who practice before generalist courts to work daily with a broad cross-section of federal law.

Similarly, because specialized judges are unlikely to apply insights from other areas of law, the market for legal services will value generalist knowledge less than if the adjudications were performed by generalist courts. This effect, too, produces a shift toward a more specialized bar.

In turn, as the bar becomes more specialized, it becomes less capable of bringing before the court insights from other areas of law, and therefore the court is less likely to be exposed to such areas than it was when it was first established. There is thus a ratchet effect that pushes in the direction of ever-increasing specialization of both judges and lawyers, posing increasing threats to the coherence of federal law.

There is strong empirical support for the proposition that specialized courts interfere with the coherence of federal law. For example, Professor Dreyfuss has analyzed the problems for the development of a coherent national policy on competition caused by vesting jurisdiction over all patent appeals in the Federal Circuit. ${ }^{199}$ Decisional authority with respect to questions of competition is now divided between the specialized Federal Circuit and the generalist, regional courts of appeals, which continue to have authority over

198 The Tax Court, for example, makes far more liberal use of stipulations than do the district courts. See H. Dubroff, supra note 9, at 290 (describing Tax Court Rule 91).

199 See Dreyfuss, supra note 13, at 53-59. 
other bodies of law affecting competition, such as antitrust. Professor Dreyfuss notes:

Patent law constitutes only a small part of competition law, and the system that patent law creates to promote innovation is only one of many ways in which innovation is facilitated by the legal system. If the [Federal Circuit] is told to encourage invention, but is permitted to see only a small part of the matrix into which patent cases fit, it is likely that it will misconceive the role that patent law plays in the larger scheme. It will overemphasize the need to reward inventors because it is the only tool with which it can further the legislative goal of promoting innovation. Conversely, it will undervalue the interest of competitors because it will not have the occasion to consider the role that vigorous competition plays in encouraging invention. ${ }^{200}$

Not only has the Federal Circuit failed to be guided by the insights of the regional courts of appeals, but these courts have not benefitted from the Federal Circuit's own experience. ${ }^{201}$

To conclude, the goal of coherence should not trump fidelity to congressional intent. There is therefore no tension between my defense of the benefits of coherence in this Part and of the benefits of unbiased interpretation of congressional intent in Part III. My more limited claim is that where it is not inconsistent with congressional intent for courts to promote the coherence of federal law, it is desirable for them to do so, and that generalist courts can perform the task better than specialized courts.

\section{An Assessment of the Different Types of Specialized Courts}

So far, I have focused on the costs of specialized courts that operate at the level of the courts of appeals. Courts of limited jurisdiction, staffed by specialized judges, decrease the effectiveness of congressional delegation to administrative agencies, and interfere with the coherent development of federal law. Courts of exclusive jurisdiction eliminate the benefits of multi-circuit consideration of legal issues. ${ }^{202}$

200 Id. at 54.

201 See id. at 59. The Federal Circuit could remedy this problem by departing from its ruling in Atari, Inc. v. JS \& A Group, 747 F.2d 1422 (Fed. Cir. 1984) (en banc), and thereby applying its expertise to other areas of competition law. See supra text accompanying notes 92-93.

202 These costs of specialization do not apply with equal force in all contexts. For example, with respect to courts of limited jurisdiction, the extent to which there 
However, the negative effects of specialized courts identified in this Article do not apply if the courts are subject to review, as of right, by the generalist, regional circuits. Then, the specialized court would be overseen by a forum that does not exhibit the systemic biases that are likely to be found in specialized courts; that is functionally well suited and capable of drawing insights from other areas of law, thereby promoting the coherence of federal law; and that is capable of engaging in dialogue designed to improve the quality of legal rules.

Thus, the negative effects discussed in this Article do not apply to courts of Types II and V in Table III-the Tax Court, OSHRC, and FMSHRC. Similarly, the negative effects would not apply to the proposed Social Security Court, as long as its decisions were subject to review as of right in the regional circuits. ${ }^{203}$

Many of the arguments in favor of specialized review of administrative action can be adequately met by specialized courts that are subject to review by the regional circuits. First, to the extent that the argument for specialization is the technical complexity of the underlying facts, ${ }^{204}$ a specialized court should be given fact-finding, rather than appellate, capability.

Consider, for example, the experience of the Federal Circuit in reviewing factual determinations. Commentators have presented strong arguments for departing from the "clearly erroneous" standard for review of factual findings set forth in Rule 52(a). ${ }^{205}$ For example, Professor Dreyfuss has noted:
A trial judge who has never read a technical document before is less likely to interpret it correctly, no matter how many expert wit- nesses are called to testify, than an appellate judge who has exten- sive experience in dealing with such matters. Thus, it seems somewhat peculiar to allow a layman's decision to stand on a tech- nical issue ... when the experienced judges of the [Federal Cir- cuit], and the experts they employ, think that the finding is wrong, but not "clearly erroneous." 206

The most desirable solution, however, is not to tinker with the mean-

are negative effects on the proce:ss of delegation depends on the structure of the specialized bar. See supra text accompanying notes 167-68. Similarly, courts of limited jurisdiction that review the decisions of several agencies are more desirable than ones that review only a single agency. See supra note 166.

203 See supra text accompanying note 126.

204 See supra text accompanying notes 32-33.

205 See Fed. R. Crv. P. 52(a); Anderson v. City of Bessemer City, 470 U.S. 564, 573-576 (1985).

206 Dreyfuss, supra note 13, at 48. 
ing of Rule 52(a), but to place the expertise at the fact-finding level. Then, appellate review of factual determinations would take place under the proper application of the "clearly erroneous" standard and could well be vested in the regional circuit courts.

Second, even when accepting the argument for specialization that adjudication should be removed from administrative agencies as a means of improving impartiality, specialized courts can still be made subject to review in the regional circuits. In fact, in the three cases in which specialized courts were established primarily to address this concern-the Tax Court, OSHRC, and FMSHRC-they were made subject to review by the generalist appellate courts.

Third, specialized courts subject to review in the regional circuits can improve the internal coherence of a statutory scheme, as can strong administrative agencies; it is not necessary to place these courts at the level of the courts of appeals.

An argument forcefully advanced in connection with the establishment of the Federal Circuit as a specialized court of patent appeals, was the need to promote the internal coherence of patent law. ${ }^{207}$ The central reason for the lack of internal coherence of federal patent law prior to the establishment of the Federal Circuit in 1982 was the absence of a strong administrative agency. As already indicated, under the prior scheme, the PTO made the initial determinations of patentability. The decisions of the PTO were reviewed by the Court of Customs and Patent Appeals. Enforcement issues, however, were not handled by the PTO or by its reviewing court but instead by the federal district courts, with appeal to the regional circuits. ${ }^{208}$ There was no single institution, either in the administrative or judicial sphere, with responsibility for the universe of patent law. Moreover, the PTO was not accorded deference by the regional circuits, due in part to its largely ex parte proceedings. ${ }^{209}$

207 See, e.g., S. ReP. No. 275, supra note 2, at 5, reprinted in 1982 U.S. CODE Cong. \& ADMIN. NEwS at 15 (accompanying bill that led to the creation of the Federal Circuit) ("The establishment of the Court of Appeals for the Federal Circuit also provides a forum that will increase doctrinal stability in the field of patent law."); Commission on Revision of the Federal Court Appellate System, Structure and Internal Procedures: Recommendations for Change, 67 F.R.D. 195, 220 (1975) (stating that "[t]he additional appellate capacity for nationally binding decisions which a national court of appeals would provide" would enhance predictability, consistency, and the establishment of a national patent policy); Dreyfuss, supra note 13, at 1-4 (discussing arguments for and against establishment of the Federal Circuit with regard to patent jurisdiction).

208 See supra text accompanying notes 61-62.

209 See Dreyfuss, supra note 13, at 21. 
I accept the conclusion of the supporters of the creation of the Federal Circuit that an engine for internal coherence was required. ${ }^{210}$ I also have no reason to doubt Professor Dreyfuss' conclusion that the Federal Circuit "has begun to make systemic improvements, developing a patent law that is both more rational and easier to apply." 211 I believe, however, that the focus for reform should have been at the bottom of the administrative lawmaking system rather than at the top. In this way, internal coherence could have been achieved without sacrificing external coherence, or incurring the other costs introduced by specialization.

The starting point for reform of the institutions administering federal patent law therefore should have been a study of the possibility of making the PTO (or a successor) a strong agency, perhaps by vesting in it responsibility not only for making determinations of patentability, but also by giving it responsibility for making initial adjudications with respect to enforcement. Then, with initial decisionmaking authority over the whole field, and adversary proceedings in the enforcement cases, the PTO could have become a strong force for internal coherence. ${ }^{212}$

There is a tradeoff between the internal coherence of a statutory scheme and the external coherence of federal law as a whole. Generalist courts may well fail to see connections between different parts of a statute and render decisions that create inconsistencies within the statute. The Federal Circuit, under the current scheme, may do better in terms of internal coherence than a strong agency subject to review in the generalist courts. However, the socially desirable resolution of the tradeoff between external coherence and internal coherence surely cannot be achieved by eliminating the forces for external coherence altogether. Rather, the proper balance should be achieved by appropriate attention to the deference that should be accorded by generalist courts to specialized administrative determinations, and in particular, to an agency's interpretations of the governing statute it administers as prescribed by Chevron, USA v. National Resources Defense Council. ${ }^{213}$

Another method for promoting internal coherence in the patent

210 See supra text accompanying notes 28-30.

211 Dreyfuss, supra note 13, at 52.

212 See id. at 73-74. I certainly have not thought deeply about the implications of such a proposal. Perhaps experts in the patent field will reject it as impractical. The point remains, however, that changing the mechanisms for appellate judicial review should have been an option of last resort.

213467 U.S. 837 (1984). 
field without wholly sacrificing external coherence would have been to create a specialized court subject to review in the generalist courts. The decisions of specialized courts with respect to questions of statutory interpretation are not due Cheoron deference by their reviewing courts, as are the decisions of administrative agencies. But specialized courts can nonetheless command the respect of their reviewing courts and thereby have informal, rather than formal, influence. For example, a study of the Tax Court found that, compared to the district courts, it was reversed less frequently on appeal, and its decisions were appealed less frequently and cited more often. ${ }^{214}$ Moreover, several landmark tax principles were first developed by the Tax Court. ${ }^{215}$ While it is difficult to draw strong conclusions from limited empirical evidence of this type, I think it is quite likely that the courts of appeals are paying attention to Justice Jackson's admonition that " $[w]$ here the statute is ... indecisive and the importance of a particular holding lies in its rational and harmonious relation to the general scheme of the tax law, ... great deference is due to the ... judgment of the Tax Court."216 Despite this deference, the generalist courts stand as a guarantee that systemic biases can be corrected.

To this point, I have explained why concerns over the complexity of facts, the combination of functions in administrative agencies, and the lack of internal coherence of statutory schemes can be addressed without the need to create specialized courts that operate at the level of the courts of appeals. The three remaining reasons for specialized courts on which I focused in Part I are the benefits of uniformity in particular statutory schemes, the legal complexity of particular statutes, and the workload of the generalist, federal courts.

As to workload, removing classes of cases from the generalist courts is likely to reduce their workload, although it would create a whole new category of cases concerning the respective jurisdictions of the generalist and specialized courts. ${ }^{217}$ But for the claim to be persuasive, it must be shown why a particular class of administrative

214 See Worthy, The Tax Litigation Structure, 5 GA. L. REv. 248, 253-54 (1971).

215 See id. at 254.

216 Arrowsmith v. Commissioner, 344 U.S. 6, 12 (1952) (Jackson, J., dissenting); see also United States v. Foster Lumber Co., 429 U.S. 32, 55 (1976) (Blackmun, J., dissenting) (citing Justice Jackson's Arrowsmith dissent with approval).

217 See, e.g., R. POSNER, supra note 13, at 157 ("Specialization is a potential source of serious boundary problems .... [E] ither one specialized court is assigned the whole case, producing underspecialization with respect to . . . issues . . . from a different field of law, or the case is split between different courts and judicial economy is lost."); Currie \& Goodman, supra note 19, at 73 ("The jurisdictional lines 
cases has a less compelling claim on the jurisdiction of the generalist courts than does, for example, diversity jurisdiction. ${ }^{218}$ Clearly, this is not the place to analyze competing claims, but it is relevant to recall that such fundamental issues as the scope of class actions ${ }^{219}$ or of the injunctive power of the federal courts ${ }^{220}$ have been resolved in the context of Social Security cases, which some believe to be relatively routine and therefore unworthy of the generalist courts. ${ }^{221}$

It is possible, however, that establishing specialized courts subject to review by the regional circuits would reduce the workload of the federal courts without giving rise to the problems analyzed in this Article. Such courts would replace the reviewing function of the district courts under schemes in which there is two-step review of the administrative determination-that is, review first in the district courts and then in the courts of appeals. ${ }^{222}$ Also, to the extent that the adjudicatory decisions of such courts are perceived as more impartial than those of administrative agencies, ${ }^{223}$ there will be fewer appeals to the courts of appeals.

Uniformity and legal difficulty have justified, to varying degrees, the vesting of exclusive jurisdiction over certain administrative areas in the D.C. Circuit, and the creation of specialized court staffed by generalist judges such as the Commerce Court, the Emergency Court of Appeals, and the Temporary Emergency Court of Appeals; these courts are classified under Types I and IV in Table III. While this arrangement eliminates the benefits of multi-circuit consideration of legal issues, it does not hamper the delegation of congressional authority or undermine the coherence of federal law. To the extent that arguments based on uniformity and legal difficulty prove compelling in the future for a particular administrative area, these arrangements are preferable to ones that raise delegation and coherence problems as well.

separating administrative from general courts should be drawn as precisely as possible in order to minimize litigation over the proper forum.").

218 See Currie \& Goodman, supra note 19 , at 64.

219 See Califano v. Yamasaki, 442 U.S. 682 (1979).

220 See Heckler v. Day, 467 U.S. 104 (1984).

221 See supra text accompanving note 47.

222 For discussions of the level at which to vest review of administrative action, see Currie \& Goodman, supra note 19; Legomsky, Forum Choices for the Review of Agency Adjudication: A Study of the Immigration Process, 71 Iowa L. Rev. 1297 (1986). For an examination of models of administrative agency review of decisions by administrative law judges, see Cass, Allocation of Authority Within Bureaucracies: Empirical Evidence and Normative Analysis, 66 B.U.L. Rev. 1 (1986).

223 See supra text accompanying notes $34-41$. 


\section{ConClusion}

I hope that this Article will contribute to the analysis of specialized courts by drawing attention to three questions that have not been explored in the academic literature. First, the specialized review of administrative action raises different issues from specialized review in non-administrative cases. Second, the specialized review of administrative action cannot be fully understood without considering its effects on all of the components of the administrative lawmaking system-a system defined by the complex interrelationships among Congress, administrative agencies, and the federal courts. Third, each of the different varieties of specialized courts raises distinct issues, and an assessment of the desirability of such courts must be carefully tailored to the type of court being analyzed. In particular, one should draw a sharp distinction between specialized courts that supplant the function of the generalist, regional courts of appeals, and specialized courts that are subject to review by the courts of appeals. 


\section{APPENDIX}

\section{A. Short-Run}

Let $x$ be the control costs that Congress expends; $\mathrm{B}(\mathrm{x})$ be the divergence costs that it bears (as a function of control costs) when the review of agency action. is performed by a generalist court; $A(x)$ be the divergence costs, as a function of control costs, that Congress bears after the replacement of generalist review with review in a court staffed by specialized judges. $B(x)$ and $A(x)$ are assumed to be convex, so that $B_{x}<0, B_{x:}>0$, and $A_{x}<0, A_{x x}>0 .{ }^{1}$

Because the replacement of generalist review with specialized review increases the divergence costs that result from a given level of control costs, $\mathrm{A}(\mathrm{x})>\mathrm{B}(\mathrm{x})$.

Congress' objective functions, before and after the creation of a specialized court, respectively, can be represented as follows:

$$
\begin{aligned}
& \text { Min } \mathrm{x}+\mathrm{B}(\mathrm{x}) \\
& \text { Min } \mathrm{x}+\mathrm{A}(\mathrm{x})
\end{aligned}
$$

The first-order conditions are given, respectively, by

$$
\begin{aligned}
& 1+\mathrm{B}_{\mathrm{x}}\left(\mathrm{x}_{\mathrm{B}}{ }^{*}\right)=0 \\
& 1+\mathrm{A}_{\mathrm{x}}\left(\mathrm{x}_{\mathrm{A}}{ }^{*}\right)=0
\end{aligned}
$$

Proposition 1: $\mathrm{x}_{\mathrm{B}}^{*}+\mathrm{B}\left(\mathrm{x}_{\mathrm{B}}^{*}\right)<\mathrm{x}_{\mathrm{A}}^{*}+\mathrm{A}\left(\mathrm{x}_{\mathrm{A}}^{*}\right)$

Proof: Given the optimality of $x_{B}{ }^{*}$, it follows that

Because $A(x)>B(x)$,

$$
\mathrm{x}_{\mathrm{B}}^{*}+\mathrm{B}\left(\mathrm{x}_{\mathrm{B}}{ }^{*}\right) \leq \mathrm{x}_{\mathrm{A}}{ }^{*}+\mathrm{B}\left(\mathrm{x}_{\mathrm{A}}^{*}\right)
$$

Thus, $\mathrm{x}_{\mathrm{B}}^{*}+\mathrm{B}\left(\mathrm{x}_{\mathrm{B}}^{*}\right)<\mathrm{x}_{\mathrm{A}}^{*}+\mathrm{A}\left(\mathrm{x}_{\mathrm{A}}^{*}\right)$.

Proposition 2: $\mathrm{x}_{\mathrm{A}}^{*}>\mathrm{x}_{\mathrm{B}}{ }^{*}$ if

(a) $\mathrm{A}_{\mathbf{x}}<\mathrm{B}_{\mathbf{x}}$

Proof: Given the first-order conditions,

$$
\mathrm{B}_{\mathrm{x}}\left(\mathrm{x}_{\mathrm{B}}{ }^{*}\right)=\mathrm{A}_{\mathrm{x}}\left(\mathrm{x}_{\mathrm{A}}{ }^{*}\right)
$$

If $A_{x}<B_{x}$, it follows that

$$
\mathrm{A}_{\mathrm{x}}\left(\mathrm{x}_{\mathrm{B}}{ }^{*}\right)<\mathrm{B}_{\mathrm{x}}\left(\mathrm{x}_{\mathrm{B}}{ }^{*}\right)
$$

Thus,

$$
\mathrm{A}_{\mathrm{x}}\left(\mathrm{x}_{\mathrm{B}}{ }^{*}\right)<\mathrm{A}_{\mathrm{x}}\left(\mathrm{x}_{\mathrm{A}}{ }^{*}\right)
$$

From $A_{x x}>0$, it follows that $x_{A}{ }^{*}>x_{B}{ }^{*}$.

If the establishment of a specialized courts increases congressional control costs by some percentage, so that $A(x)=r B(x)+s$, where $r>1$ and $s>0$, condition (a) is satisfied. This functional

1 The first and second derivatives of $B(x)$ with respect to $x$ are represented by $B_{x}$ and $B_{x x}$, respectively. 
relationship is a plausible one, although it certainly does not exhaust the domain of plausible functions.

\section{B. LONG-RUN}

Let $d$ be the level of congressional delegation to the administrative agency; $W(d)$ be the benefit to Congress of delegation if the agency is wholly loyal; $\mathrm{B}(\mathrm{x}, \mathrm{d})$ be the divergence costs that Congress bears, as a function of control costs and delegation, when the review of agency action is performed by a generalist court; $A(x, d)$ be the divergence costs, as a function of control costs and delegation, after the replacement of generalist review with specialized review. $W(d)$ is assumed to be concave, so that $W_{d}>0$ and $W_{d d}<0$. B(x,d) and $A(x, d)$ are assumed to be convex, so that $B_{x}<0, B_{x x}>0, B_{d}>0$, $B_{d d}>0, B_{x x} B_{d d}-\left(B_{x d}\right)^{2}>0 .{ }^{2}$ Because the replacement of generalist review with specialized review increases the divergence costs that result from a given level of control costs, $A(x, d)>B(x, d)$.

Congress' objective functions, before and after the creation of a specialized court, respectively, can be represented as follows:

$$
\begin{aligned}
& \operatorname{Max} W(d)-x-B(x, d) \\
& \operatorname{Max} W(d)-x-A(x, d)
\end{aligned}
$$

The first-order conditions, before the creation of a specialized court, are:

$$
\begin{gathered}
-1-\mathrm{B}_{\mathrm{x}}\left(\mathrm{x}_{\mathrm{B}}{ }^{*}, \mathrm{~d}_{\mathrm{B}}{ }^{*}\right)=0 \\
\mathrm{~W}_{\mathrm{d}}\left(\mathrm{d}_{\mathrm{B}}{ }^{*}\right)-\mathrm{B}_{\mathrm{d}}\left(\mathrm{x}_{\mathrm{B}}{ }^{*}, \mathrm{~d}_{\mathrm{B}}{ }^{*}\right)=0
\end{gathered}
$$

The first-order conditions, after the creation of a specialized court, are:

Proposition 3:

$$
\begin{gathered}
-1-A_{x}\left(x_{A}^{*}, d_{A}^{*}\right)=0 \\
W_{d}\left(d_{A}^{*}\right)-A_{d}\left(x_{A}^{*}, d_{A}^{*}\right)=0
\end{gathered}
$$

$\mathrm{W}\left(\mathrm{d}_{\mathrm{B}}{ }^{*}\right)-\mathrm{x}_{\mathrm{B}}{ }^{*}-\mathrm{B}\left(\mathrm{x}_{\mathrm{B}}{ }^{*}, \mathrm{~d}_{\mathrm{B}}{ }^{*}\right)>\mathrm{W}\left(\mathrm{d}_{\mathrm{A}}{ }^{*}\right)-\mathrm{x}_{\mathrm{A}}{ }^{*}-\mathrm{A}\left(\mathrm{x}_{\mathrm{A}}{ }^{*}, \mathrm{~d}_{\mathrm{A}}{ }^{*}\right)$

Proof: Given the optimality of $x_{B}{ }^{*}$ and $d_{B} *$, it follows that $\mathrm{W}\left(\mathrm{d}_{\mathrm{B}}{ }^{*}\right)-\mathrm{x}_{\mathrm{B}}{ }^{*}-\mathrm{B}\left(\mathrm{x}_{\mathrm{B}}{ }^{*}, \mathrm{~d}_{\mathrm{B}}{ }^{*}\right) \geq \mathrm{W}\left(\mathrm{d}_{\mathrm{A}}{ }^{*}\right)-\mathrm{x}_{\mathrm{A}}{ }^{*}-\mathrm{B}\left(\mathrm{x}_{\mathrm{A}}{ }^{*}, \mathrm{~d}_{\mathrm{A}}{ }^{*}\right)$ Because $A(x, d)>B(x, d)$, Thus,

$$
W\left(d_{A}^{*}\right)-x_{A}^{*}-B\left(x_{A}^{*}, d_{A}^{*}\right)>W\left(d_{A}^{*}\right)-x_{A}^{*}-A\left(x_{A}^{*}, d_{A}^{*}\right)
$$

$\mathrm{W}\left(\mathrm{d}_{\mathrm{B}}{ }^{*}\right)-\mathrm{x}_{\mathrm{B}}{ }^{*}-\mathrm{B}\left(\mathrm{x}_{\mathrm{B}}{ }^{*}, \mathrm{~d}_{\mathrm{B}}{ }^{*}\right)>\mathrm{W}\left(\mathrm{d}_{\mathrm{A}}{ }^{*}\right)-\mathrm{x}_{\mathrm{A}}{ }^{*}-\mathrm{A}\left(\mathrm{x}_{\mathrm{A}}{ }^{*}, \mathrm{~d}_{\mathrm{A}}{ }^{*}\right)$

Proposition 4: $\mathrm{d}_{\mathrm{A}} *<\mathrm{d}_{\mathrm{B}}{ }^{*}$ and $\mathrm{x}_{\mathrm{A}}{ }^{*}>\mathrm{x}_{\mathrm{B}}{ }^{*}$ if

(a) $B_{x d}<0$ and $A_{x d}<0$, and

(b) $A_{x}<B_{x}, A_{d}>B_{d}$ 
Proof: From (1) and (3), it follows that $B_{x}\left(x_{B}{ }^{*}, d_{B}{ }^{*}\right)=$ $A_{x}\left(x_{A}^{*}, d_{A}^{*}\right)$. Because $A_{x}<B_{x}$, it follows that $A_{x}\left(x_{B}{ }^{*}, d_{B}{ }^{*}\right)<$ $B_{x}\left(x_{B}{ }^{*}, d_{B}{ }^{*}\right)$. Therefore, $A_{x}\left(x_{B}{ }^{*}, d_{B}{ }^{*}\right)<A_{x}\left(x_{A}{ }^{*}, d_{A}{ }^{*}\right)$. Because $A_{x x}>0$ and $A_{x d}<0$, this inequality is satisfied by the following conditions: $\mathrm{x}_{\mathrm{A}}{ }^{*}>\mathrm{x}_{\mathrm{B}}{ }^{*}$ and $\mathrm{d}_{\mathrm{A}}{ }^{*}<\mathrm{d}_{\mathrm{B}}{ }^{*}$.

To show that these conditions also satisfy (2) and (4), I will first assume that $d_{A} *<d_{B} *$ and then prove that (2) and (4) are met when $\mathrm{x}_{\mathrm{A}}{ }^{*}>\mathrm{x}_{\mathrm{B}}{ }^{*}$. If $\mathrm{d}_{\mathrm{A}}{ }^{*}<\mathrm{d}_{\mathrm{B}}{ }^{*}$, then $\mathrm{W}_{\mathrm{d}}\left(\mathrm{d}_{\mathrm{B}}{ }^{*}\right)<\mathrm{W}_{\mathrm{d}}\left(\mathrm{d}_{\mathrm{A}}{ }^{*}\right)$, as $\mathrm{W}_{\mathrm{dd}}<0$.

From (2) and (4), it follows that

$$
\mathrm{B}_{\mathrm{d}}\left(\mathrm{x}_{\mathrm{B}}{ }^{\prime \prime}, \mathrm{d}_{\mathrm{B}}{ }^{*}\right)<\mathrm{A}_{\mathrm{d}}\left(\mathrm{x}_{\mathrm{A}}{ }^{*}, \mathrm{~d}_{\mathrm{A}}{ }^{*}\right)
$$

But, for $x_{A}{ }^{*}>x_{B}{ }^{*}$ and $d_{A}{ }^{*}<d_{B}{ }^{*}$, and given that $B_{d d}>0, B_{x d}<0$, it follows that $B_{d}\left(x_{B}{ }^{*}, d_{B}{ }^{*}\right)>B_{d}\left(x_{A}{ }^{*}, d_{A}{ }^{*}\right)$. Because $A_{d}>B_{d}, x_{A}{ }^{*}>x_{B}{ }^{*}$ and $d_{A} *<d_{B} *$ satisfy (2) and (4).

In summary, $\mathrm{x}_{\mathrm{A}}{ }^{*}>\mathrm{x}_{\mathrm{B}}{ }^{*}$ and $\mathrm{d}_{\mathrm{A}} *<\mathrm{d}_{\mathrm{B}} *$ are sufficient conditions for maximization. It is necessary, but not sufficient, for one of these relationships to hold.

Condition (a) holds when the absolute value of the rate of change of divergence costs with respect to control costs increases with increasing levels of delegation. Indeed, if $B_{x d}<0, B_{x}\left(x, d_{1}\right)<$ $B_{x}\left(x, d_{2}\right)$, for $d_{1}>d_{2}$. But, $B_{x}<0$. Therefore, taking absolute values, $\left|B_{x}\left(x, d_{1}\right)\right|>\left|B_{x}\left(x, d_{2}\right)\right|$. Stated differently, the condition holds when a fixed expenditure of control costs reduces divergence costs more when the level of delegation is high than when that level of low. I believe that such a condition has intuitive appeal.

If the establishment of a specialized courts increases congressional control costs by some percentage, so that $A(x, d)=r B(x, d)+$ $\mathrm{s}$, where $\mathrm{r}>1, \mathrm{~s}>0$, conditions (b) are satisfied. This functional relationship is a plausible one, although it certainly does not exhaust the domain of plausible functions.

For help with these proofs, I am grateful to Lewis Kornhauser. 